\title{
Does the Mediterranean water shrew Neomys anomalus (Soricidae, Eulipotyphla) expand the eastern part of the distribution range?
}

\author{
Oleg A. Ermakov, Alina V. Mishta, Boris I. Sheftel, Ekaterina V. Obolenskaya, \\ Georgiy A. Lada, Natalia V. Bystrakova, Alexander B. Ruchin, \\ Andrey A. Lissovsky*
}

\begin{abstract}
The Mediterranean water shrew Neomys anomalus is sparsely distributed across the major part of Eastern Europe. There is a large amount of new information about the enlargement of the distribution range of the species during last 2 to 3 decades. We analysed species distribution, variation of cytochrome $b$ gene and character of appearance of new records on species distribution. We suggest that the "expansion" of the Mediterranean water shrew is rather a result of more thorough faunal studies than of a natural expansion of the species range.
\end{abstract}

How to cite this article: Ermakov O.A., Mishta A.V., Sheftel B.I., Obolenskaya E.V., Lada G.A., Bystrakova N.V., Ruchin A.B., Lissovsky A.A. 2020. Does the Mediterranean water shrew Neomys anomalus (Soricidae, Eulipotyphla) expand the eastern part of the distribution range? // Russian J. Theriol. Vol.19. No.2. P.112-130. doi: 10.15298/rusjtheriol.19.2.02.

KEY WORDS: Neomys anomalus, distribution, cytochrome $b$, species distribution modelling, Eastern Europe.

OlegA.Ermakov[oaermakov@list.ru],NataliaV.Bystrakova[natvibys@mail.ru],Penza State University,Krasnaya40, Penza 440026, Russia; Alina V.Mishta [amishta@izan.kiev.ua], I. I. Schmalhausen Institute of Zoology, B. Khmelnytskogo 15, Kyiv 01030, Ukraine; Boris I. Sheftel [borissheftel@yahoo.com], Severtsov Institute of Ecology and Evolution RAS, Leninskiy pr. 33, Moscow 119071, Russia; Georgiy A. Lada [esculenta@mail.ru],Derzhavin Tambov State University, Internatsional'naya 33, Tambov 392000,Russia; Alexander B. Ruchin [ruchin.alexander@gmail.com], Joint Directorate of the Mordovia State Nature Reserve and National Park "Smolny", Krasnaya 30, Saransk 430005, Russia; Ekaterina V. Obolenskaya [obolenskaya@zmmu.msu.ru], Andrey A. Lissovsky [andlis@zmmu.msu.ru], Zoological Museum of Moscow State University, Bolshaya Nikitskaya 6, Moscow 125009, Russia.

\section{Расширяет ли малая кутора Neomys anomalus (Soricidae, Eulipotyphla) восточную часть своего ареала?}

\section{О.А. Ермаков, А.В. Мишта, Б.И. Шефтель, Е.В. Оболенская, Г.А. Лада, Н.В. Быстракова, А.Б. Ручин, А.А. Лисовский}

\begin{abstract}
РЕЗЮМЕ. Малая кутора Neomys anomalus спорадично распространена по большей части Восточной Европы. В течение последних 2-3 десятилетий появился большой объем новой информации о расширении ареала этого вида. Мы проанализировали распространение вида, изменчивость гена цитохром $b$ и характер появления данных о новых находках вида. Мы предполагаем, что "расширение" ареала малой куторы скорее является результатом интенсификации фаунистических исследований, чем следствием действительного расширения ареала этого вида.
\end{abstract}

КЛЮЧЕВЫЕ СЛОВА: Neomys anomalus, распространение, цитохром $b$, экологическое моделирование, Восточная Европа.

\section{Introduction}

The range of the Mediterranean water shrew (Neomys anomalus Cabrera, 1907) extends from Europe to Asia Minor (Hutterer et al., 2010). It is sparsely distributed across the major part of Eastern Europe. New informa-

* Corresponding author tion about the enlargement of the distribution range in the southern, northern and eastern directions began to arrive during last 2 to 3 decades. The Mediterranean water shrew was captured in south-western Iran, which is about $1000 \mathrm{~km}$ to the south from known distribution limits (Esmaeili et al., 2008), and was also found in Estonia (Balčiauskas et al., 2016), $700 \mathrm{~km}$ to the north 
of the most northern locality for this species in Poland. In Russia, during last decades the species was found in several regions for the first time: Mordovia Republic, Kaluga, Tambov and Penza Regions (Lada \& Sokolov, 2000, 2012; Sokolov \& Lada, 2007; Borodin, 2013; Ruchin et al., 2018; our data), far outside its known distribution.

This poses the question of the reasons for these new reports. Is this a consequence of species distribution change or a result of increased native populations, which were so sparse previously that it was not possible to capture animals using traditional trapping methods? It should be noted that some "new" findings of the shrew are the result of the analysis of museum collections; animals were captured and stored in a museum with incorrect species identification. In such cases, the Mediterranean water shrew was mixed up with the Eurasian water shrew ( $N$. fodiens Pennant, 1771), although these two species have notable morphological differences (Zaitsev et al., 2014).

In this study, we used species distribution modelling as well as analysis of mitochondrial cytochrome $b$ sequence variation for the comparison of two alternate hypotheses on the reasons of the "expansion" of the distribution range of $N$. anomalus: actual range shifts vs. previous mistakes in species identification, along with increasing success of species detection using more effective methods.

\section{Material and methods}

\section{Species distribution modelling}

We analysed all occurrence records of the Mediterranean water shrew in Eastern Europe, available from literature, museum collections, and our field data. The whole dataset consisted of 239 records (Appendix 1), some of which were made from territory that suffered from anthropogenic transformation during the time passed from the date of capture or were obtained from pellets analysis (no geographical coordinates of animal occurrence). Such records were excluded from the analysis. The remaining dataset had irregular spatial distribution, including spatial aggregations. Therefore, we filtered the dataset, selecting one observation locality per $50 \times 50-\mathrm{km}$ square. The resulting dataset, which was used in the species distribution modelling, contained 69 localities.

The spatial frame of the analysis included a grid with a resolution of $0.02^{\circ}$ in geographic longitude/latitude WGS84-based projection. We used 86 environmental variables: WorldClim 19 "bioclimatic" variables (http:// www.worldclim.org; Hijmans et al., 2005), elevation, maximum snow depth, slopes curvature and steepness and 63 MODIS generalised average monthly data layers (9 months of 2004 per seven spectral bands; http://glcf. umiacs.umd.edu/data, Eastern Hemisphere only) as environmental descriptors. To correct for the non-random spatial distribution of locations and to control the set of background points, we prepared a Maxent bias file that describes the spatial distribution of sampling efforts. Specifically, we selected all available records (1149 points) of representatives of Soricidae from the studied region and constructed a $5-\mathrm{km}$ buffer around each. The bias file had the value " 1 " across the studied region, but " 10 " under the buffers. The same dataset was used for reducing the number of environmental variables: we learnt principal components analysis (PCA) on the set of raster cells that intersect the 5-km buffers mentioned above and projected the result on the entire raster extent. Thus, principal components explain the variation in the environment around all sampled localities. Overall, 23 PCs, explaining $95 \%$ of variance, were selected for further analysis.

Species distribution modelling was carried out in MaxEnt version 3.4.1 (Phillips et al., 2019). To prevent over-parameterisation of the species distribution model, we compared the AICc values across the set of models with different values of regularisation multiplier $(0.75,1$, $2,3,5$ ) and different sets of feature types ("LQ", "LQH", "LQP", "LQHP”) (Muscarella et al., 2014).

\section{Molecular analysis}

We sampled DNA from two museum specimens of the Mediterranean water shrew, originated from the most eastern part of the range (Tambov $52.7216 \mathrm{~N}, 41.5267 \mathrm{E}$, and Penza 53.6804 N, 42.2019 E regions). The DNA was extracted according to a standard procedure, including treatment with sodium dodecyl sulphate and proteinase $\mathrm{K}$ and subsequent phenol-chloroform extraction (Sambrook et al., 1989). To deal with degraded DNA from old museum samples, we used three overlapping primer pairs specific to Neomys in gene cyt $b$ (1140 bp) amplification: tRNAGlu - 5'-ATC GTT GTT ATT CAA CTA TAA GAA C-3' and cytb 403R - 5'-YCC YCA RAA TGA TAT TTG YCC TCA-3'; cytb 389F - 5'-GTT ATA GCC ACT GCC TTT ATA G-3' and cytb_746R - 5'-TAATTG TCC GGG TCT CCG AGT A-3'; cytb 614F - 5'-TWT TCC TYC ATG AAA CAG GAT C-3' ${ }^{-}$and tRNAThr 5' -TTT TGG TTT ACAAGA CCA GTG TAT-3' (Igea et al., 2015). Each PCR reaction contained $50 \mathrm{mM}$ Tris- $\mathrm{HCl}$ (pH 8.9), $20 \mathrm{mM}$ ammonium sulphate, $20 \mu \mathrm{M}$ EDTA, $150 \mu \mathrm{g} / \mathrm{ml}$ bovine serum albumin, dNTPs $(200 \mu \mathrm{M}$ of each), $2 \mathrm{mM} \mathrm{MgCl}, 15$ pmol of each primer, 2 units of Taq polymerase and 0.1 to $0.2 \mu \mathrm{g}$ DNA in a final volume of $25 \mu \mathrm{l}$. The reaction conditions were an initial denaturation of $3 \mathrm{~min}$ at $95^{\circ} \mathrm{C}$, followed by 32 cycles of denaturation $\left(30 \mathrm{~s}\right.$ at $\left.95^{\circ} \mathrm{C}\right)$, annealing $\left(30 \mathrm{~s}\right.$ at $\left.54^{\circ} \mathrm{C}\right)$ and extension $\left(40 \mathrm{~s}\right.$ at $\left.72^{\circ} \mathrm{C}\right)$. The PCR products were analysed using electrophoresis in 6\% PAAG with subsequent staining with ethidium bromide and visualisation under UV light. Sequencing was done on an ABI 3500 automated capillary sequencer (Applied Biosystems) with the ABI Prism Big Dye Terminator Cycle Sequencing Ready Reaction Kit3.1, using the same primers. Sequences were aligned manually and checked for unexpected stop codons using BioEdit 7.0 (Hall, 1999). The genetic distance matrices ( $p$-distances) between haplogroups were calculated in the MEGA7 software (Kumar et al., 2016). Haplotype networks were constructed using the median 
joining method in the PopART software (Leigh \& Bryant, 2015). The obtained sequences were deposited in GenBank (MT855469, MT855470). Additionally, we used 22 sequences downloaded from GenBank (AB175099-100 (Ohdachi et al., 2006); DQ991049-55 (Castiglia et al., 2007); LK936659-71 (Igea et al., 2015)).

\section{Morphology}

Measurements of the body, tail and feet of Mediterranean and Eurasian water shrews was taken from museum labels. All specimens were identified using a complex of external and cranial features (Pucek, 1984). We used specimens from collections of the following institutions: the National Museum of Natural History at the National Academy of Sciences of Ukraine (NMNH, Ukraine), the Zoological Museum of Taras Shevchenko National University of Kyiv (KNU, Ukraine), the theriological collection of the Department of Monitoring and Animal Conservation of I.I. Schmalhausen Institute of Zoology (IZAN, Ukraine), the Zoological Museum of Ivan Franko National University of Lviv (LNU, Ukraine), the National Museum of Natural History (Lviv, LNHM, Ukraine), the Zoological Museum of the National University of Uzhhorod (UzhNU) (Uzhhorod, Ukraine), the zoological collection of Mykola Hohol State University of Nizhyn (NU) (Nizhyn, Ukraine), the theriological collection of the Mammal Research Institute Polish Academy of Sciences (MRIPAS) (Bialowieza, Poland), the Zoological Museum of the Penza State University (ZMPSU) (Penza, Russia), the Zoological Museum of the Moscow State University (ZMMU) (Moscow, Russia).

\section{Results}

\section{Distribution model}

The optimal model selected had a regularisation multiplier of 0.75 and linear and quadratic features only. Algorithm converged after 1100 iterations; AUC was 0.927 . The predicted distribution of suitable habitats for the Mediterranean water shrew did not form a continuous area and rather consisted of a set of small patches of suitable habitats. These patches mostly forested areas in river valleys, were separated by bands of unsuitable or less suitable habitats (Fig. 1). The largest agglomerations of suitable habitats were confined to forests in the basin of the middle Oder River, valleys of the Vistula River and its tributaries: Kamienna and Narew, in the Carpathian Mountains (Danube basin: Tisza and Prut Rivers valleys), forests of the Neman River and its tributary Viliya valleys, the middle Dniester basin, tributaries of the Dnieper River (Samara, Vorskla, Psyol, Sula, Teteriv, Irpin, Desna, Sozh, Prypiat), forests of the Seversky Donets River and the tributary Oskol and in mountainous Crimea. The patch of suitable habitats was situated in the basin of the Ushacha River, tributary of Daugava (Zapadnaya Dvina). Habitat suitability decreased in an eastern direction; the main agglomerations of suitable habitats were situated in forests of the Voronezh River basin (Don River tributary) and the Moksha River basin (Oka tributary, Volga basin).

The Mediterranean water shrew was never found in two areas predicted by our modelling, namely the area in Northern Caucasus and Taman Peninsula as well as the Trans-Volga region near Samara Bend.

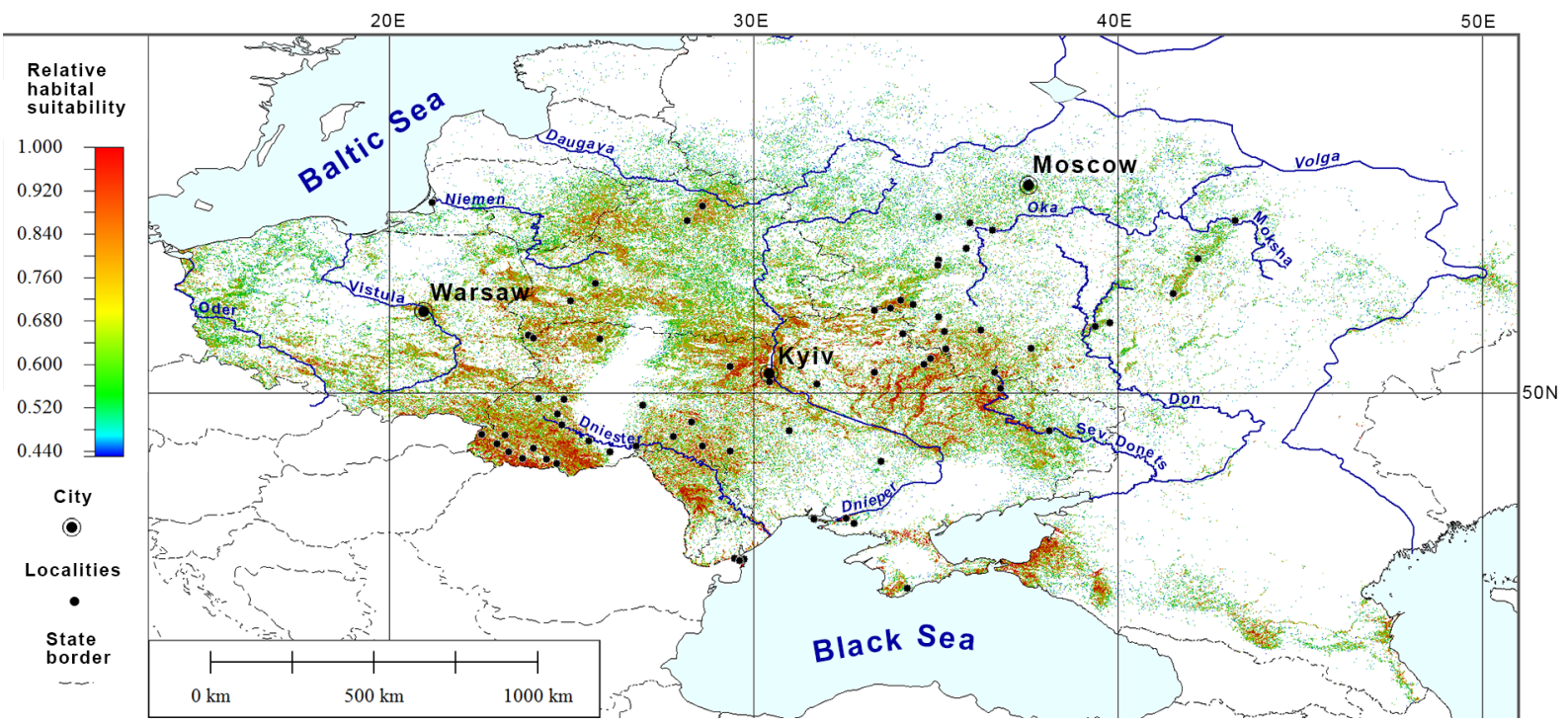

Fig. 1. Model of habitats suitable for Neomys anomalus after analysis of environmental predictors using Maxent. Relative suitability is shown by colour gradient. Areas of low habitat suitability are masked using the Maxent maximum training sensitivity plus specificity threshold. Localities, included in the analysis are shown. 


\section{Mitochondrial variation}

Both studied specimens of Mediterranean water shrew from the Penza and Tambov regions had the same haplotype, similar (difference $0.3 \%$ ) to the haplotypes from Belgorod region and Belorussia from GenBank. There are three major haplogroups in the network of $N$. anomalus haplotypes (Fig. 2), all of which have a distinct geographic distribution. The first consisted of Iberian specimens and thus corresponded to $N$. $a$. anomalus. The remaining two consisted of non-Iberian specimens and therefore represented $N$. a. milleri. One of the haplogroups within N. a. milleri included Eastern European samples, while the second included samples from the rest of Europe, excluding the Iberian Peninsula. The difference ( $p$-distance) between subspecies was $6.9 \pm$ $0.6 \%$, while that between haplogroups of $N$. a. milleri was $3.7 \pm 0.5 \%$. The average distance within "milleri" haplotypes $(2.4 \pm 0.3 \%)$ was about 2.5 times larger than average distance within "anomalus" $(0.9 \pm 0.2 \%)$.

\section{Sample from Estonia}

The northernmost localities for which the occurrence of the Mediterranean water shrew was found are situated on the territory of Estonia (Balčiauskas et al., 2016). Three $N$. anomalus specimens were found during the revision of collection of the University of Tartu Museum (UTM). Our species distribution modelling did not confirm the existence of suitable habitats for $N$. anomalus in the territory of Estonia (Fig. 1). Keeping in mind the theoretical possibility of mixing up of $N$. anomalus and $N$. fodiens, we compared body measurements of the Estonian sample with those of water shrews from the rest of Eastern Europe. According to our data, values for foot length do not overlap in samples of two Neomys species collected from one geographical region (Table).
Therefore, the length of the hind foot could serve as a rough diagnostic tool for these two species in sympatry. We suggest that all body measurements (including foot length) of specimens described by Balčiauskas et al. (2016) as N. anomalus from Estonia lie completely within the variation of $N$. fodiens from this country and adjacent territories. Besides, there is a negative correlation of body size with latitude (Kryštufek \& Quadracci, 2008); northern populations should be smaller in size. This rule is true for $N$. fodiens (Balčiauskas et al., 2014). Estonian $N$. anomalus (more northern) specimens were larger than those from Lithuania (more southern) (Balčiauskas et al., 2016). Consequently, we suggest a thorough additional investigation of specimens of $N$. anomalus from the UTM collection.

\section{Discussion}

The Mediterranean water shrew has a wide but fragmented distribution range from Western Europe to the Volga region and Asia Minor (Zaitsev et al., 2014). Our modelling results confirm that the range in Eastern Europe consists of a number of fragments of various sizes, with different habitat suitability. The largest patches of suitable habitats are located at least in the basins of nine larger rivers. Taking into account the ecological relation of water shrews to water (Spitzenberger, 1990), disconnection of the distribution range into patches in different large river basins, together with low density across the range (Zaitsev et al., 2014), could indicate real distribution fragmentation at present. The high parameterisation of our optimal model (regularisation coefficient of 0.75 ) suggests regional ecological peculiarity and weak general ecological trends.

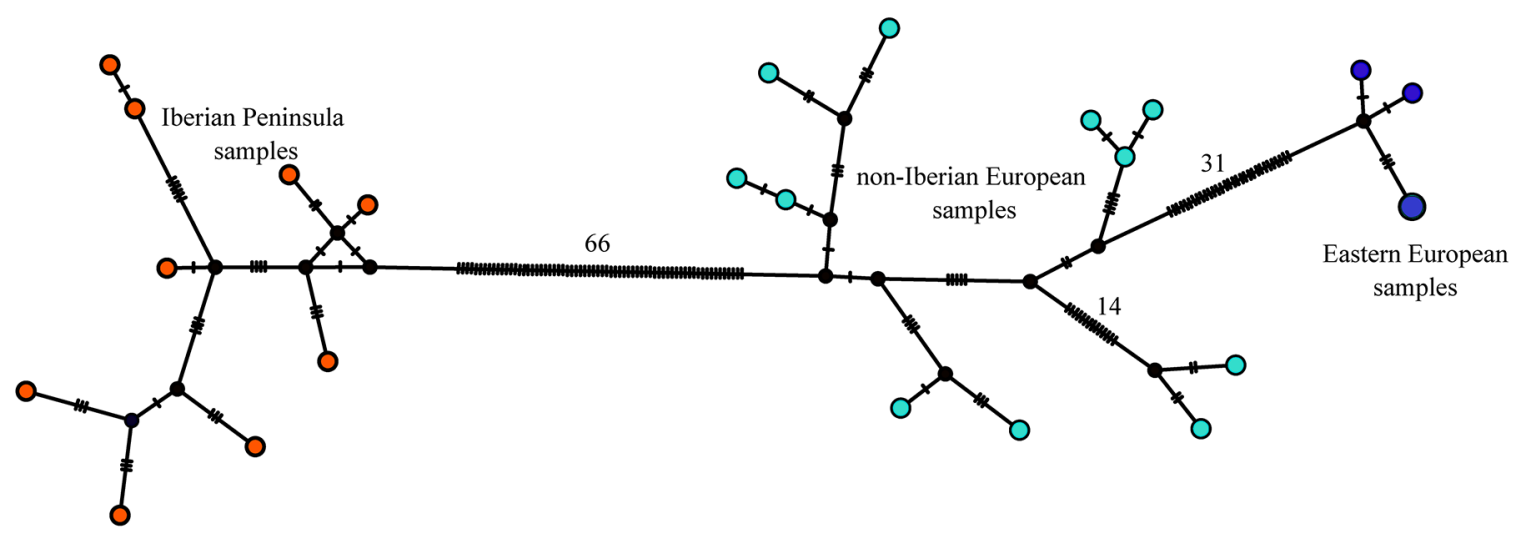

Fig. 2. Haplotype network of Iberian, non-Iberian and Eastern European specimens of Neomys anomalus, based on analysis of the mitochondrial cytochrome $b$ gene $(1140 \mathrm{bp})$. Hash marks reflect the number of mutational differences between haplotypes separated by more than one mutation. 
Table. Body measurements (mm) of Neomys anomalus and N. fodiens from Estonia, Lithuania, Poland, Belarus, Ukraine and Russia. Data are from labels of museum collections and publications.

\begin{tabular}{|c|c|c|c|}
\hline Region & $\begin{array}{l}\text { Body length } \\
\text { min-max (avg) }\end{array}$ & $\begin{array}{l}\text { Tail length } \\
\text { min-max (avg) }\end{array}$ & $\begin{array}{l}\text { Foot length } \\
\text { min-max (avg) }\end{array}$ \\
\hline \multicolumn{4}{|c|}{ Neomys anomalus from Estonia } \\
\hline Estonia (Balčiauskas et al., 2016) & $\begin{array}{c}70-84(78) \\
n=3\end{array}$ & $\begin{array}{c}51-58(54.6) \\
n=3\end{array}$ & $\begin{array}{c}16.5-17(16.8) \\
n=3\end{array}$ \\
\hline \multicolumn{4}{|c|}{ N. anomalus } \\
\hline $\begin{array}{l}\text { Belarus } \\
\text { (our data, Savarin \& Savarina, 2019; Savarin, 2020) }\end{array}$ & $\begin{array}{c}59.1-77(67.68) \\
\mathrm{n}=19\end{array}$ & $\begin{array}{c}41-51.3(45.5) \\
n=19\end{array}$ & $\begin{array}{c}13-15(14.25) \\
n=19\end{array}$ \\
\hline Kyiv region (Ukraine) & $\begin{array}{c}66-74.5(71.2) \\
n=9\end{array}$ & $\begin{array}{c}39.5-49.5(44.53) \\
n=9\end{array}$ & $\begin{array}{c}13.8-15.2(14.29) \\
n=9\end{array}$ \\
\hline Zakarpattia region (Ukraine) & $\begin{array}{c}57-88(74.48) \\
n=21\end{array}$ & $\begin{array}{c}42-52(47.67) \\
n=21\end{array}$ & $\begin{array}{c}14-15.7(15.16) \\
\mathrm{n}=21\end{array}$ \\
\hline Lviv region (Ukraine) & $\begin{array}{c}63-79(70.9) \\
n=20\end{array}$ & $\begin{array}{c}46-56(51.05) \\
n=20\end{array}$ & $\begin{array}{c}13-16(14.88) \\
\mathrm{n}=20\end{array}$ \\
\hline Odessa region (Ukraine) & $\begin{array}{c}64-79(72.1) \\
n=5\end{array}$ & $\begin{array}{l}\begin{array}{l}44.5-54(50.68) \\
n=5\end{array} \\
\end{array}$ & $\begin{array}{c}\begin{array}{c}14.5-15.4(14.98) \\
n=5\end{array} \\
\end{array}$ \\
\hline Sumy region (Ukraine) & $\begin{array}{c}\begin{array}{c}67.8-75(70.86) \\
n=5\end{array} \\
\end{array}$ & $\begin{array}{c}38.8-44(43.4) \\
n=5\end{array}$ & $\begin{array}{c}\begin{array}{c}13.6-14.7(14.1) \\
n=5\end{array} \\
\end{array}$ \\
\hline Lugansk region (Ukraine) (Abelentsev, 1967) & $\begin{array}{c}71-76.1(73.07) \\
n=4\end{array}$ & $\begin{array}{c}43-53(47.65) \\
n=4\end{array}$ & $\begin{array}{c}\begin{array}{c}13.2-15(14.38) \\
\mathrm{n}=4\end{array} \\
\end{array}$ \\
\hline Crimea & $\begin{array}{c}60-89.4(76.14) \\
n=21\end{array}$ & $\begin{array}{c}44.5-58.3(51.9) \\
\mathrm{n}=21\end{array}$ & $\begin{array}{c}15-18(16.28) \\
n=23\end{array}$ \\
\hline Bryansk region (Russia) & $\begin{array}{c}63-74(69.28) \\
n=9\end{array}$ & $\begin{array}{c}42-55(48.33) \\
n=9\end{array}$ & $\begin{array}{c}13.8-15(14.14) \\
n=9\end{array}$ \\
\hline Kursk region (Russia) & $\begin{array}{c}68-75.2(72.52) \\
n=11\end{array}$ & $\begin{array}{c}45-51.5(48.39) \\
n=11\end{array}$ & $\begin{array}{c}13.7-15(14.45) \\
n=11\end{array}$ \\
\hline Mordovia (Russia) (Borodin, 2103) & $\begin{array}{c}67-76(72.8) \\
\mathrm{n}=15 \\
\end{array}$ & $\begin{array}{c}44.7-54.1(50.32) \\
\mathrm{n}=15\end{array}$ & $\begin{array}{c}13.4-15.4(14.51) \\
\mathrm{n}=15\end{array}$ \\
\hline Penza region (Russia) & $\begin{array}{c}69 \\
n=1\end{array}$ & $\begin{array}{c}45 \\
\mathrm{n}=1\end{array}$ & $\begin{array}{c}14 \\
\mathrm{n}=1\end{array}$ \\
\hline Białowieża (Poland) & $\begin{array}{c}65-83.2(75.0) \\
n=28\end{array}$ & $\begin{array}{c}39-49.1(43.4) \\
\mathrm{n}=28\end{array}$ & $\begin{array}{c}14-16.5(14.92) \\
n=28\end{array}$ \\
\hline Białowieża (Poland) (Dehnel, 1950) & $\begin{array}{c}67-85 \\
\mathrm{n}=65 \\
\end{array}$ & $\begin{array}{c}42-52 \\
\mathrm{n}=65\end{array}$ & $\begin{array}{c}14-15.4 \\
\mathrm{n}=65\end{array}$ \\
\hline Lithuania (Balčiauskas et al., 2012) & - & $\begin{array}{c}41-48.2(44.7) \\
n=3\end{array}$ & $\begin{array}{c}14-15.2(4.0) \\
n=3\end{array}$ \\
\hline \multicolumn{4}{|c|}{ N. fodiens } \\
\hline Belarus (our data; Savarin, 2020) & $\begin{array}{c}70.5-102(78.93) \\
n=7\end{array}$ & $\begin{array}{c}54-65(58.57) \\
n=7\end{array}$ & $\begin{array}{c}16-19(17.79) \\
\mathrm{n}=7\end{array}$ \\
\hline Kyiv region (Ukraine) & $\begin{array}{c}78-85(81.37) \\
n=7\end{array}$ & $\begin{array}{c}61-69(63.44) \\
n=7\end{array}$ & $\begin{array}{c}16.5-19(18.06) \\
n=8\end{array}$ \\
\hline Zakarpattia region (Ukraine) & $\begin{array}{c}63-105(79.62) \\
n=90\end{array}$ & $\begin{array}{c}\text { 53-68 (61.09) } \\
n=90\end{array}$ & $\begin{array}{c}16-21(18.08) \\
n=90\end{array}$ \\
\hline Lviv region (Ukraine) & $\begin{array}{c}63-87(77.36) \\
n=22\end{array}$ & $\begin{array}{c}53-67(60.02) \\
n=22\end{array}$ & $\begin{array}{c}16.5-19(17.62) \\
n=22\end{array}$ \\
\hline Sumy region (Ukraine) & $\begin{array}{c}82.5-94.2(87.9) \\
n=6\end{array}$ & $\begin{array}{c}59-66.5(61.18) \\
n=6\end{array}$ & $\begin{array}{c}17-19.8(18.15) \\
n=6\end{array}$ \\
\hline Lugansk region (Ukraine) (our data; Abelentsev, 1967) & $\begin{array}{c}66.1-87(79) \\
n=7\end{array}$ & $\begin{array}{c}60-69.6(63.44) \\
n=7\end{array}$ & $\begin{array}{c}18.7-22(19.79) \\
n=7\end{array}$ \\
\hline Bryansk region (Russia) & $\begin{array}{c}71.5-86(79.52) \\
n=12\end{array}$ & $\begin{array}{c}53.5-62(58.77) \\
n=12\end{array}$ & $\begin{array}{c}17.1-19(18.08) \\
n=12\end{array}$ \\
\hline Kursk region (Russia) & $\begin{array}{c}81.7-90(83.11) \\
n=9\end{array}$ & $\begin{array}{c}62.5-78(68.24) \\
n=9\end{array}$ & $\begin{array}{c}17.3-19.4(18.94) \\
n=9\end{array}$ \\
\hline Białowieża (Poland) & $\begin{array}{c}71-93(81.05) \\
n=78\end{array}$ & $\begin{array}{c}54-69.2(61.62) \\
n=78\end{array}$ & $\begin{array}{c}17.2-19.5(18.43) \\
\mathrm{n}=78\end{array}$ \\
\hline Białowieża (Poland) (Dehnel, 1950) & $70-96$ & $52-72$ & $16-19.5$ \\
\hline Lithuania (Balčiauskas et al., 2012) & - & $\begin{array}{c}50.5-73.1(61.78) \\
n=84\end{array}$ & $\begin{array}{c}16.3-19.6(18.0) \\
\mathrm{n}=84\end{array}$ \\
\hline Estonia (Balčiauskas et al., 2014) & - & $\begin{array}{c}48-68(59.31) \\
\mathrm{n}=18\end{array}$ & $\begin{array}{c}16-19(17.53) \\
n=18\end{array}$ \\
\hline
\end{tabular}


Genetic data also support the long-standing formation of the Mediterranean water shrew population in Eastern Europe. According to Igea et al. (2015), the divergence between $N$. a. anomalus and $N$. a. milleri took place about 400000 years ago and, most probably, was related to one of the Middle Pleistocene glaciations. The ancestral population of $N$. anomalus became isolated in the Iberian Peninsula, while the remaining population (milleri) could occupy Eastern Europe and Asia Minor during interglacials. Since all known haplotypes from Eastern Europe belong to a separate haplogroup, we can hypothesise that the eastern and western populations of $N$. a. milleri diverged later than the split between $N$. a. anomalus and N. a. milleri. The long history of formation of $N$. a. milleri is supported by high genetic distances within this taxon $-2.4 \%$ on average, with a maximum of $4.2 \%$.

Turning back to the main task of this study, it would be interesting to describe the dynamics of the accumulation of data on $N$. anomalus distribution. The species was described at the beginning of the 20th century on the basis of a specimen from Spain (Cabrera, 1907). The same year, but later, another species, N. milleri (Mottaz, 1907), was described from the territory of Switzerland; this name was considered as a synonym of $N$. anomalus for a long time. Recently, Igea et al. (2015) suggested the separation of Iberian water shrews (N. a. anomalus) and animals from the rest of Europe ( $N$. a. milleri) into two independent species. The subspecies of the Eurasian water shrew was described from the southern Crimea in 1917 - N. fodiens mokrzeckii Martino, 1917 (Martino \& Martino, 1917); later, this subspecies was considered as a taxon within the Mediterranean water shrew. The author Ognev (1928) listed the Mediterranean water shrew (as N. soricoides) in Eastern Europe for the first time; Ognev's checklist contains two localities: Białowieża and Kyiv Province (I.G. Pidoplichko collection). Around this time, N. anomalus was found in Belarus not only in Białowieża (1913), but in the Gomel (1929 and 1930) region (Turov, 1955; Serzhanin, 1961; Serzhanin et al., 1967). The checklist from 1944 (Bobrinskiy et al., 1944) expanded the list of the Mediterranean water shrew records in Eastern Europe by two items only: Southern Bessarabia and Voronezhskiy Zapovednik (Lavrov \& Lavrov, 1938). There is no mention of this species from Belarus in the text of Bobrinskiy' checklist; however, there is a dot in the Brest region shown on the map. The mammal identification guide of Gromov et al. (1963) contains almost the same localities for the Mediterranean water shrew in Eastern Europe comparing to that of Bobrinskiy et al. (1944). The minor difference included new information about the occurrence of the species in Transcarpathia, the suggestion of this species' presence in Belarus as well as doubts on the correct species identification of the specimens from Voronezhskiy Zapovednik, mentioned above. Two years later, Bobrinskiy et al. (1965) notably enlarged our knowledge on the distribution of $N$. anomalus. Changes concerned the territory of Ukraine and Belarus, while the Russian range was still restricted to records from Voronezhskiy
Zapovednik. The catalogue of mammals of the USSR (Gromov \& Baranova, 1981) almost repeats information from the previous checklist (Bobrinskiy et al., 1965), with exception of the absence of a mention of the Mediterranean water shrew from Russia.

Thus, in 1981, at least some Russian zoologists doubted the existence of $N$. anomalus in Russia, while museum specimens with incorrect species identification were kept in collections for a long time. The author E.S. Ptushenko found the Mediterranean water shrew in the Kursk Region in 1926-27. The shrew was collected in five localities of Dmitrievskiy District as well is in the districts Lgovskiy and Sudzhanskiy. These specimens were kept in the Zoological Museum of Moscow State University (ZMMU) and later identified by M.V. Zaitsev. Further, E.S. Ptushenko collected the Mediterranean water shrew near Belgorod in the valley of the Seversky Donets River in 1926; the specimen was passed to the ZMMU. In 1936, L.G. Morozova-Turova captured $N$. anomalus in the territory of Mordovskiy Zapovednik (Inorki plot) (Borodin, 2013). Later, 15 specimens were collected by L.P. Borodin and P.L. Borodin in a water meadow of the Pushta River in 1975, 1979-1981; two of them are kept in the ZMMU.

The data set from the Ukraine territory was also notably larger than it was reflected in published checklists. The first data on the Mediterranean water shrew were indeed collected in 1926 (Ognev, 1928; Pidoplichko, 1929) - ten skulls from pellets of barn owls were collected by E. Kititsyn in the Vyrva River valley near Radomyslska station in Kyiv Province (Korostensky District of Zhytomyr Region now). The adult female of the Mediterranean water shrew was collected by E. Kititsyn in the same locality in autumn 1926, and this material was analysed by I. Pidoplichko. Another specimen, collected by S. Ivanov near Uman (Cherkassy Region) in 1925, was handed to I. Pidoplichko. A large data set on the distribution and density of the Mediterranean water shrew in Right-bank Ukraine and Western Ukraine was generated after analysis of pellets of birds of prey, mainly in the first half of the 20th century (Pidoplichko, 1927, 1929, 1932, 1937, 1963; Sokur, 1963). More than 600 localities of 24 regions were investigated; $N$. anomalus was found in 75 localities of 12 regions. The knowledge on $N$. anomalus distribution in Western Ukraine was extended by Tatarynov (1956). In the territory of Left-bank Ukraine, single Mediterranean water shrews were revealed in the districts Brovarsky and Yagotinsky of the Kyiv region (Abelentsev \& Pidoplichko, 1956) and near Poltava City (Gavrilenko, 1946 (1947)). Later, four specimens of $N$. anomalus were collected in the valley of the Seversky Donets River in the summer of 1961 (Kremenskoy District, Lugansk Region) (Abelentsev, 1966, 1967).

After the 1980s, information on the Mediterranean water shrew distribution in Eastern Europe grew rapidly (Appendix I). Three localities were found in Lithuania. One specimen was collected in 2009 in the Neman River delta, and two specimens were found during the examination of museum collections (Balčiauskas \& Balčiauskiene, 2012). 
Several specimens of $N$. anomalus were collected in the Vitebsk region of Belarus, in the territory of Berezinsky Zapovednik (Kashtalyan, 1999; Kashtalyan \& Springer, 2012; Igea et al., 2015). In the $20^{\text {th }}$ century, new localities in Brest (Bereza Town vicinities) and Vitebsk (Ushachskiy District) were found (Savarin, Molosh, 2017; Savarin, 2019 a, b, c).

After 1997, in Ukraine, the species was found across Sumy region in the districts Seredina-Budsky, Gluhivsky, Romensky, Sumsky and Lebedinsky (Merzlikin, 1999; Mishta, 1999, 2003; Mishta \& Shevchenko, 2003; Podoprigora \& Merzlikin, 2003; Gavris et al., 2007; Merzlikin \& Sheverdyukova, 2008; Mishta, 2008; Merzlikin \& Sheverdyukova, 2010). A single specimen was collected in the valley of the Seversky Donets River near Verkhniy Saltov Village, Kharkiv region, in October 2005 (Zorya, 2008; Tokarskiy \& Zorya, 2013). The first record of the Mediterranean water shrew from the Chernigiv region came from the analysis of pellets of tawny owls in 2008 (Zaitseva \& Gnatina, 2010). The species was found in the south of the regions Kherson and Nikolaev (Gizenko, 1967; Selyunina, 2005) in the Danube delta Reserve of Odessa (Fedorchenko, 1992; Mishta, 2018). The most recent record from the Dnepropetrovsk region (right bank of the Dnieper River) near Kryvyi Rih was uploaded by V. Sevidov to the UkrBin database (http://ukrbin.com/ show image.php?imageid=52354).

The Mediterranean water shrew has always been a rare species in Ukraine, with an unstable abundance over time. According to data came from the first half of the 20th century, in Right-bank Ukraine, this species was less common in pellets of birds of prey than other shrews such as the common shrew, the Eurasian pygmy shrew, the bicolored white-toothed shrew and the Eurasian water shrew (Abelentsev \& Pidoplichko, 1956). In the last 50 years, notable parts of habitats suitable for $N$. anomalus were destroyed or transformed by human activity (swamp drainage, dam construction, deforestation, development and ploughing up of the wetlands). The species was included in the Red Data Book of Ukraine (1994, 2009). Its density in suitable habitats is maintained at a fairly low level - relative density is no more than one to two individuals per 100 traps/days; usually below 0.5 individuals. The percentage of the total catch for this species is usually below $1.5 \%$. There is a tendency to an even greater decline in the number of the species over the last 30 years (Mishta, 2009).

In Russia, the species was registered in the Kaluga region in "Ugra" National Park in 2004 for the first time. Later, single specimens of the Mediterranean water shrew were captured in Belyaevskoe, Yugorskoe (Yukhnovskiy District), Galkinskoe (Dzerzhinskiy District) and Berezichskoe (Ulyanovskiy District) forestries of this National Park as well as in "Kaluzhskie Zaseki" Zapovednik (Ulyanovskiy District) (Alekseev et al., 2006, 2011, 2014; Koryavchenkov, 2017).

The species was registered in four localities of Khvastovicheskiy District in 2011 (Koryavchenkov, 2017) and in Ferzikovskiy District in 2014 (S. Alekseev, personal communication).
The Mediterranean water shrew was registered in the south-eastern part of the Bryansk Region, within the districts Trubchevskiy, Suzemskiy and Komarichskiy. The major part of these observations was made in the territory of "Bryanskiy Les" Zapovednik (Mishta, 2005; Sitnikova \& Mishta, 2006, 2008). Outside the Zapovednik borders, the Mediterranean water shrew was found in Komarichskiy District in 2004 and in the regional natural monument "Nerusso-Sevniy" in 2005 (Mishta, 2005; Sitnikova \& Mishta, 2008).

Recently, the Mediterranean water shrew from the districts Korenevskiy and Kurskiy, Kursk region, was mentioned in several publications (Zherdeva et al., 2009; Zherdeva, 2017), but unfortunately there is no information on species identification in these publications. Inaccurate information about the presence of $N$. anomalus in the Oryol region was published in the Mammals of Russia checklist (Bannikova \& Lebedev, 2012); the Dmitrievskiy District of the Kursk region and the neighbouring Dmitrovskiy District of the Oryol region were mixed up when citing specimens collected by E. Ptushenko.

In the Belgorod region, the single recent registration was made by Yu.M. Kovalskaya in the "Belogorye" Zapovednik, "Yamskaya step" plot in 2007 (Igea et al., 2015; Shapovalov, 2019). The occurrence of N. anomalus in Lipetsk and Voronezh regions was established within "Usmanskiy Bor" (forest). Most records were from the territory of Voronezhskiy Zapovednik, which occupies the northern part of this forest. The last case took place in July 2014 (Sapelnikov \& Sapelnikova, 2015). The only specimen registered outside of the Zapovednik was a dead female found during summer 1991 at the south-western edge of Usmanskiy Bor (Klimov \& Khitsova, 1996; Klimov, 2011, 2013, 2018). There is additional information about a wider distribution of $N$. anomalus in the Lipetsk region (Nedosekin et al., 1996; Parshina, 1997); however, the data source is unknown. In 1995, one specimen was supposedly collected by M.V. Ushakov in a water meadow of the Don River in the territory of "Galichya Gora" Zapovednik (Sarychev et al., 1995; Klimov \& Khitsova, 1996). Nevertheless, this report was recognised as erroneous (Klimov, 2011). The very author of this "finding”, M.V. Ushakov (2009), considers the Mediterranean water shrew as "probably extinct in the region". This species was not included in later editions of the Red Data Book of Lipetsk region (Konstantinov, 2006; Alexandrov, 2014). The Mediterranean water shrew is known from the Tambov region by the single finding in Vlasovskoye peatland near Tambov (Lada \& Sokolov, 2000, 2012; Sokolov \& Lada, 2007). Two specimens were collected (1993 and 1997) in the Lyangas River valley, in the vicinity of Alexandrovka village in Zemetchinskiy District of the Penza region (our data). In the Mordovia Republic, the Mediterranean water shrew continues to live in Mordovskiy Zapovednik (Ruchin et al., 2018).

Recently, $N$. anomalus was found in 21 regions of Ukraine and in Crimea: four of these regions were added to the list during 1997-2019 (Chernigov, Sumy, Khar- 
kov, Dnepropetrovsk Regions), as well as eight regions of central Russia. The species was found after 1980 for the first time in four of these regions, namely Bryansk, Kaluga, Tambov and Penza. The species was found and kept in museum collections, but it was misidentified as $N$. fodiens in three regions: Kursk, Belgorod and Mordovia Republic (Borodin, 2013).

It is significant that for most cases of $N$. anomalus registration on the periphery of the range, the species was found during long studies in field stations. Such studies use various kinds of traps, including pitfalls. The stations belong to Nature Reserves (Białowieża Forest, Belogorye, Berezinskiy, Bryanskiy les, Voronezhskiy, Kaluzhskie zaseki, Mordovskiy), National Parks (Desnyansko-Starogutskiy, Ugra), natural monuments (Nerusso-Sevniy, Lovatyanka, Vytebet and Obelna Rivers, green area of Khvastovichi settlement), other traditional field stations (Pershinskaya station of MOIP, Vlasovskoye peatland near Tambov, biological centre of Voronezh State University "Venevitinovo", vicinities of Alexandrovka village in Zemetchinskiy District of Penza Region). No increasing numbers of the Mediterranean water shrew were registered somewhere in Eastern Europe. Thus, there was no reason for a dispersion of animals from zone of higher density to the periphery of the distribution range.

In summary, all studied animals belong to one compact haplogroup that was registered only in Eastern Europe. Consequently, if dispersion of water shrews is taking place, one can expect such dispersion within Eastern Europe only. The highly fragmented structure of $N$. anomalus distribution in this region makes the recent expansion of this rare species to the periphery of the range through large areas of unsuitable habitats less possible. The major part of new registrations of the Mediterranean water shrew is confined to places where long-term observations, focused on the investigation of the faunal composition, take place. This indicates a change in the thoroughness of faunal studies rather than a natural expansion of the species range. We hypothesise that one of the reasons of the "rarity" of $N$. anomalus during the 20th century was rather a social phenomenon: zoologists did not expect to find this species because of its extremely low density. As a result, specimens were not transferred to museums or were misidentified due to the lack of thorough attention.

ACKNOWLEDGMENTS. The authors are grateful to S.K. Alekseev (Eco-biological centre Kaluga region), A.V. Rogulenko (National Park Ugra), A.S. Klimov (Voronezh State University), E.V. Sitnikova (Bryansk Forest Nature Reserve), D.S. Mosina (Moscow). A. Abramov (St. Petersburg) and N. Dokuchaev (Magadan) made a valuable comments on the text of the manuscript. This study was supported by the Russian Science Foundation; Grant number 18-14-00093.

\section{References}

Abelentsev V.I. 1966. [About the eastern border of the Mediterranean water shrew range] // [4th inter-university zoogeographic conference: abstracts.] Odessa. P.6-7. [in Russian]
Abelentsev V.I. 1967. [A new find of Neomys anomalus in Ukraine] // Vestnik Zoologii. No.4. P.65-68. [in Russian, with English summary]

Abelentsev V.I., Pidoplichko I.G. 1956. [Order Insectivores Insectivora] // [Fauna of Ukraine.] Kyiv: AS URSR Publ. Vol.1. No.1. P.70-228. [in Ukrainian]

Alekseev S.K. \& Rogulenko A.V. 2014. [Mammals] // [Vertebrates of the national park "Ugra". Vol.10. Flora and fauna of national parks]. Moskva: Izdatel'stvo Komissii RAN po sokhraneniyu biologicheskogo raznoobraziya. P.63-78. [in Russian]

Alekseev S.K., Dudkovsky N.I., Margolin V.A. \& Rogulenko A.V. 2011. [Fauna of vertebrates of the Kaluga region.] Kaluga: AKF Politop. 190 p. [in Russian]

Alekseev S.K., Koryavchenkov D.M. \& Rogulenko A.V. 2006. [Insectivores of the Galkinsky forestry of the Ugra National Park] // [Nature and history of Pougorye. Vol.4.] Kaluga: IC "Postkriptum". P.55-56. [in Russian]

Alexandrov V.L. (ed.) 2014. [Red Book of the Lipetsk region. Vol.2. Animals.] Lipetsk. 484 p. [in Russian]

Balčiauskas L. \& Balčiauskienė L. 2012. Mediterranean water shrew, Neomys anomalus Cabrera, 1907 - a new mammal species for Lithuania // North-Western Journal of Zoology. No.8. P.367-369.

Balčiauskas L., Balčiauskienė L. \& Timm U. 2014. Bergmann's rule for Neomys fodiens in the middle of the distribution range // Central European Journal of Biology. Vol.9. P.1147-1154.

Balčiauskas L., Balčiauskienė L. \& Timm U. 2016. Mediterranean water shrew (Neomys anomalus): range expansion northward// Turkish Journal of Zoology. Vol.40. P.103-111.

Bannikova A.A. \& Lebedev V.S. 2012. Order Eulipotyphla // Pavlinov I.Ya. \& Lissovsky A.A. (eds.). The Mammals of Russia: A taxonomic and Geographic Reference (Archive of the Zoological Museum of MSU. Vol. 52). M.: KMK Sci Press. P.25-72.

Bobrinskiy N.A., Kuznetsov B.A. \& Kuzyakin A.P. 1944. [Identification guide to the Mammals of the USSR]. Moscow: Nauka. 440 p. [in Russian]

Bobrinskiy N.A., Kuznetsov B.A. \& Kuzyakin A.P. 1965. [Identification guide to the Mammals of the USSR]. Moscow: Prosvescheniye. 382 p. [in Russian]

Borodin P.L. 2013. [Mediterranean water shrew in the Mordovskiy Nature Reserve] // Proceeding of the Mordovskiy State Reserve. Vol.11. P.109-124. [in Russian]

Cabrera A. 1907. Three new Spanish insectivores // The annals and magazine of natural history. Vol.20. P.212-215.

Castiglia R., Annesi F., Aloise G. \& Amori G. 2007. Mitochondrial DNA reveals different phylogeographic structures in the water shrews Neomys anomalus and $N$. fodiens (Insectivora: Soricidae) in Europe // Journal of Zoological Systematics and Evolutionary Research. Vol.45. P.255-262.

Dehnel A. 1950. [Studies on the genus Neomys Kaup] // Annales Universitatis Marie Curie-Skłodowska. Sectio C. LublinPolonia. Vol.5. P.1-63 [in Polish, with English summary]

Dulitsky A.I. 2001. Biodiversity of Crimea. Mammals: Natural history, Status, Conservation, Perspective. Simperfol: Sonat Press. 208 p. [in Russian]

Esmaeili H.R., Gholamhosseini G., Teimory A. \& Krystufek B. 2008. Noteworthy record of the Mediterranean water shrew (Neomys anomalus) from south-western Iran (Mammalia: 
Soricomorpha) // Turkish Journal of Zoology. Vol.32. No.2. P.163-166.

Fedorchenko A.A. 1992. [Insectivorous of the lower Danube River] // [First all-union meeting on the biology of insectivorous mammals] Moskva: IC RAN . P.162-163. [in Russian]

Gavrilenko M.I. 1946 (1947). [New animals and birds of the Poltava region] // [Scientific notes of Poltava Pedagogical Institute.] Poltava. P.121-128. [in Ukrainian]

Gavris G.G., Kuzmenko Yu.V., Mishta A.V. \& Kotserzhinska I.M. 2007. [Fauna of vertebrates of Desnyansko-Starogutsky National Park] Sumy: Kozatskyy val Publ. 127 p. [in Ukrainian]

Gizenko A.I. 1967. [Fauna of mammals of the Black Sea Reserve] // [Scientific conference dedicated to the 40th anniversary of the Black Sea Biosphere Reserve] Kyiv: Naukova dumka. P.20-23. [in Russian]

Gromov I.M. \& Baranova G.A. (eds.). 1981. [Catalogue of mammals of USSR (Pliocene to Recent)]. MoscowLeningrad: Nauka. 455 p. [in Russian]

Gromov I.M., Gureev A.A., Novikov G.A., Sokolov I.I., Strelkov P.P. \& Chapsky K.K. 1963. [Mammals of the fauna of USSR, Parts 1. (Guides on the Russian fauna published by Zoological Institute of Academy of Science of USSR, 83)]. Moscow, Leningrad: Izdatelstvo Akademii nauk SSSR. 641 p. [in Russian]

Hall T.A. 1999. BioEdit: A user friendly biological sequence alignment editor and analysis program for Windows 95/98/ NT // Nucleic Acids Symposium Series. Vol.41. P.95-98.

Hijmans R.J., Cameron S.E., Parra J.L., Jones P.G. \& Jarvis A. 2005. Very high resolution interpolated climate surfaces for global land areas // International Journal of Climatology. Vol.25. No.15. P.1965-1978.

Hutterer R., Amori G., Kryštufek B., Yigit N., Mitsain G., Meinig H., Bertolino S. \& Palomo L.J. 2010. Neomys anomalus // The IUCN Red List of Threatened Species 2010: e.T29657A9512098. Downloaded on 08 October 2020.

Igea J., Aymerich P., Bannikova A.A., Gosálbez J. \& Castresana J. 2015. Multilocus species trees and species delimitation in a temporal context: application to the water shrews of the genus Neomys // BMC Evolutionary Biology. Vol.15. No.209. P.1-16.

Kashtalyan A.P. \& Springer A.M. 2012. [Long-term dynamics of the number of small mammals in the forest ecosystems of the Berezinskiy Biosphere Reserve] // I.A. Zhigarev (Ed.). [Behavior, ecology and evolution of animals: monographs, articles, reports. Scientific collection of Ryazan S.A.Esenin State University РГУ (Zoology Series). Vol.3.] Ryazan: NP "Golos gubernii” Publ. P.191-214. [in Russian]

Kashtalyan A.P. 1999. [Materials on the species composition and geographical distribution of shrews in Belarus] // Bol'shakov V.N. at al. (eds.) [Biology of insectivorous mammals: abstracts.] Kemerovo: IC KemSU. P.50-53. [in Russian]

Klimov A.S. \& Khitsova L.N. 1996. [Class Mammals - Mammalia] // [Natural resources of the Voronezh region. Vertebrate. Cadastre.] Voronezh: AOZT "Biomik". P.160-202. [in Russian]

Klimov A.S. 2011. [Mediterranean water shrew Neomys anomalus Cabrera, 1907] // Negrobov O.P. (ed.) [Red Book of the Voronezh region. Vol.2. Animals.] Voronezh: NPO "Modek". P.355-356. [in Russian]

Klimov A.S. 2013. [Perennial abundance dynamics and the modern state of small mammalian species in lowland swamps of the Usmansky pine forest (Voronezh region)] // Povolzhskiy Journal of Ecology. Vol.1. P.42-50. [in Russian, with English summary]

Klimov A.S. 2018. [Mediterranean water shrew Neomys anomalus (Cabrera, 1907)] // Negrobov O.P., Numerov O.D. (eds.) [Red Book of the Voronezh region. Vol.2. Animals.] Voronezh: Tsentr dukhovnogo vozrozhdeniya Chernozemnogo kraya. P.404. [in Russian]

Konstantinov V.M. (ed.) 2006. [Red Book of the Lipetsk region. Vol.2. Animals.] Voronezh: Istoki. 256 p. [in Russian]

Koryavchenkov D.M. 2017. [Mediterranean water shrew Neomys anomalus Cabrera, 1907] // Antokhina V.A. (ed.) [Red Book of the Kaluga region. Vol.2. Animals.] Kaluga: OOO "Vash dom". P.334. [in Russian]

Kryštufek B. \& Quadracci A. 2008. Effects of latitude and allopatry on body size variation in European water shrews // Acta Theriologica. Vol.53. No.1. P.39-46.

Kumar S., Stecher G. \& Tamura K. 2016. MEGA7: Molecular Evolutionary Genetics Analysis version 7.0 // Molecular Biology and Evolution. Vol.33. P.1870-1874.

Kyjko A., Gorban L.I. \& Matejchyk V.I. 2005. [Red data book species of vertebrate animals in protected ecosystems of Volyn Polissia and Roztochchia] // [State and biodiversity of Shatsk national nature park ecosystems. Materials of Scientific conference. 16-18 September 2005.] Lviv: Ivan Franko National University. P.41-43. [in Ukrainian]

Kyseliuk O.I. 2002. [Population of small mammals of forest ecosystems of the north-eastern macroslope of the Ukrainian Carpathians] // [Bulletin of Luhansk Taras Shevchenko National University. Biological Science.] Vol.1. No.45. P.15-18. [in Ukrainian]

Lada G.A. \& Sokolov A.S. 2000. [Mediterranean water shrew Neomys anomalus Cabrera, 1907] // Ponomarev N.I. et al. (eds.) [Red Book of the Tambov region: Animals.] Tambov: IC "Tambovpoligrafizdat". P.318. [in Russian]

Lada G.A. \& Sokolov A.S. 2012. [Mediterranean water shrew Neomys anomalus Cabrera, 1907] // Petrova N.P. et al. (eds.) [Red Book of the Tambov region: Animals.] Tambov: OOO "Izdatel'stvo Yulis". P.322. [in Russian]

Lavrov L.S. \& Lavrov V.S. 1938. [Two new forms from the order Chiroptera and Insectivora for the Voronezh region] // Bulletin of Moscow Society of Naturalists. Biological series. Vol.47. No.5-6. P.404-405. [in Russian, with English summary]

Leigh J.W. \& Bryant D. 2015. PopART: Full-feature software for haplotype network construction // Methods of Ecology and Evolution. Vol.6. P.1110-1116.

Martino V.E. \& Martino E.V. 1917. [New data on mammals of mountain Crimea.] // Notes of the Crimean Society of Naturalists and Nature Lovers. Vol.7. P.1-2. [in Russian]

Merzlikin I.P. \& Sheverdyukova A.V. 2008. [New meeting of the Mediterranean water shrew Neomys anomalus Cabrera (Insectivora, Soricidae) in the Sumy region] // [Ecology and conservancy: scientific collection.] Sumy: Sumy A.S. Makarenko State Pedagogical University Publ. P.127-129. [in Russian] 
Merzlikin I.P. \& Sheverdyukova A.V. 2010. [New records of the Mediterranean water shrew, Neomys anomalus Cabrera (Insectivora, Soricidae), in the Sumy oblast] // Proceedings of the Theriological School. Vol.10. P.135-136. [in Ukrainian, with English summary]

Merzlikin I.P. 1999. [Neomys anomalus Cabrera (Insectivora, Soricidae) on the North-East of Ukraine] // Vestnik Zoologii. Vol.33. No.1-2. P.100. [in Russian]

Mishta A.V. \& Shevchenko S.N. 2003. [Small mammals of the Desnyansko-Starogutsky National Natural Park (preliminary communication)] // Syutkin S.I. (ed.) [Problems of preservation of landscape, coenotic and species diversity of the Dnieper basin: scientific collection.] Sumy: IC SumDPU. P.159-164. [in Russian]

Mishta A.V. 1999. [Finding of the Mediterranean water shrew, Neomys anomalus (Mammalia: Insectivora) on the territory of the Desnyansko-Starogutsky National Natural Park] // Andrienko T.L. et al. (eds.) [Prospects for the development of the ecological network and the creation of transboundary protected areas in the Desna basin: proceedings of the meeting of the Russian-Ukrainian workgroup on the creation of a transboundary protected natural area "Bryansk and Starogutsk forests".] Moskva: Vsemirnyy fond dikoy prirody. P.71. [in Russian]

Mishta A.V. 2003. [Shrews (Soricidae, Mammalia) of the Desnyansko-Starogutsky National Natural Park] // [The role of nature reserves in the maintenance of biodiversity (Proceedings of the conference dedicated to the 80th anniversary of the Kaniv Nature Reserve, Kaniv, September 9-11, 2003)]. Kaniv. P.250-252. [in Russian]

Mishta A.V. 2005. [Rare species of insectivorous mammals (Soricidae, Insectivora) of the Bryansk region] // Fedotov Yu.P. (eds.) [Study and protection of biological diversity of the Bryansk region. Materials for maintaining the Red Book of the Bryansk Region. Vol.1.] Trubchevsk: "Kirillitsa" Publ. P.163-168. [in Russian]

Mishta A.V. 2008. [New finds of rare species of shrews (Insectivora, Mammalia) in Ukraine] // [Finds of animals of the Red Book of Ukraine.] Kyiv: Institute of Zoology NAS Ukraine. P.212-218. [in Ukrainian]

Mishta A.V. 2009. [Mediterranean water shrew Neomys anomalus (Cabrera, 1907)] // Akimov I. (Ed.). [Red Book of Ukraine. Animals.] Kyiv: "Globalkonsalting”. P.489.

Mishta A.V. 2013. [Contemporary state and recommendations for monitoring of terrestrial mammals of wetlands of international significance Kilija delta] // [Ecology of wetlands and peatlands. Materials of international scientific and practical conference "Methods and technologies of strategic planning of territories development. Management of wetlands of international importance in Ukraine" Kyiv, 01.02.2013.] Kyiv: "DIA". P.185-190. [in Ukrainian]

Mishta A.V., Rusin M. Yu. \& Ghazali M.A. 2018. [New findings of medittranean shrew Neomys anomalus Cabrera, 1907 and bicoloured white-toothed shrew Crocidura leucodon Hermann, 1780] // Akimov I.A. et al. (eds.) [Materials for the 4th edition of the Red Data Book of Ukraine. Series: "Conservation Biology in Ukraine".] Vol.7(2). Kyiv, Schmalhausen Institute of Zoology NASc Ukraine. P.30. [in Ukrainian]

Mottaz C. 1907. Préliminaires a nos "Etudes de Micromammalogie". Description du Neomys milleri, sp. nova. // Mémoires de la Société Zoologique de France. Vol.20. P.20-32.
Muscarella R., Galante P.J., Soley-Guardia M., Boria R.A., Kass J.M., Uriarte M. \& Anderson R.P. 2014. ENMeval: An $\mathrm{R}$ package for conducting spatially independent evaluations and estimating optimal model complexity for Maxent ecological niche models // Methods in Ecology and Evolution. Vol.5. No.11. P.1198-1205.

Nedosekin V.Yu., Klimov S.M., Sarychev V.S. \& Alexandrov V.N. 1996. [Vertebrates of the Lipetsk region and their protection.] Lipetsk: LSPI \& LIIT Publ. 80 p. [in Russian]

Ognev S.I. 1928. [Mammals of Eastern Europe and Northern Asia, V. 1. Insectivores and bats]. Moscow, Leningrad: Glavnauka. 631 p. [in Russian]

Ohdachi S. D., Hasegawa M., Iwasa M. A., Vogel P., Oshida T., Lin L.-K. \& Abe H. 2006. Molecular phylogenetics of soricid shrews (Mammalia) based on mitochondrial cytochrome b gene sequences: with special reference to the Soricinae // Journal of Zoology. Vol.270. P.177-191.

Parshina Yu.E. 1997. [Mediterranean water shrew Neomys anomalus Cabrera, 1907] // Klimov S.I., Kuznetsova V.T., Sarychev V.S. (eds.) [Red Book of the Lipetsk region. Rare and endangered animal species.] Lipetsk: Lipetsk State Pedagogical Institute. P.9. [in Russian]

Phillips S.J., Dudík M. \& Schapire R.E. 2019. Maxent software for modeling species niches and distributions (Version 3.4.1). Available from: <http://biodiversityinformatics. amnh.org/open source/maxent/>. Accessed: 2 apr. 2019.

Pidoplichko I.G. 1927. [Theriological notes. I. On distribution of some Western European mammals in Ukraine] // [Proceedings of the Zoological Museum (Kyiv)] No.3. P.185-192. [in Ukrainian]

Pidoplichko I.G. 1929. [Theriological notes. II. Overview of the distribution of g. Neomys in Ukraine] // [Proceedings of the Zoological Museum (Kyiv)] No.7. P.67-85 (65-83). [in Ukrainian]

Pidoplichko I.G. 1932. [Analysis of pellets for 1925-1929]. // [Materials for the district study of small animals and birds feeding on them. Vol.1.] Kyiv. P.5-75. [in Ukrainian]

Pidoplichko I.G. 1937. [The results of the study of pellets for 1924-1935] // [Proceedings of the Zoological Museum (Kyiv)]. No.19. P.101-107. [in Ukrainian]

Pidoplichko I.G. 1963. [Materials for the study of the fauna of small mammals using the pellets method] // [Proceedings of the Zoological Museum (Kyiv)] No.32.P.3-28. [in Ukrainian]

Podoprigora R.I. \& Merzlikin I.R. 2003. [Old records of Mediterranean water shrew Neomys anomalus Cabrera (Insectivora, Soricidae) in Sumy Region] // Syutkin S.I. (ed.) [Problems of conservation of landscape, coenotic and species diversity of the Dnieper basin. Collection of scientific works to the 75th anniversary of the "Mikhailovskaya virgin land" Reserve.] Sumy: SumDPU Publ. P.158-159. [in Russian]

PucekZ. (Ed.) 1984. [Key to determination of mammals of Poland.] Warszawa: Polish Scientific Publishers. 364 p. [in Polish]

Ruchin A.B., Alekseev S.K., Artaev O.N. \& Semishin G.B. 2018. [New information on the fauna of small mammals (Rodentia, Insectivora) of Mordovia caught in the soil traps] // Proceeding of the Mordovia State Reserve. Vol.20. P.223-228. [in Russian]

Sambrook J., Fritsch E.F. \& Maniatis T. 1989. Molecular cloning: a laboratory manual. NewYork: Cold Spring Harbor Laboratory Press. 1626 p. 
Sapelnikov S.F. \& Sapelnikova I.I. 2015. [Registration of regional rare species of small mammals in the vicinity of the Voronezh nature reserve] // Blochin G.I. (ed.) [Materials of 6-th international conference "Conservation of animal diversity and hunting husbandry of Russia”.] Reutov: Era press. P.296-297. [in Russian]

Sarychev V.S., Nedosekin V.Yu. \& Ushakov M.V. 1995. [New data on rare species of terrestrial vertebrates of the Lipetsk region] // [Theses of the scientific conference dedicated to the founder of the Lipetsk Regional Museum M.P. Trunov.] Lipetsk: Lipetsk State Pedagogical University. P.173-175. [in Russian]

Savarin A. \& Savarina V. 2019. The Mediterranean water shrew (Neomys anomalus) in northern Belarus: new records and identification criteria // Theriologia Ukrainica. Vol.18. P.137-143.

Savarin A.A. \& Molosh A.N. 2017. [About finding the Mediterranean water shrew (Neomys anomalus Cabrera, 1907) on the territory of waste water treatment plant in Bereza town (Brest region)] // Odessa National University Herald. Biology. Vol.22. No.1(40). P.71-77. [in Russian, with English summary]

Savarin A.A. 2019a. [About distribution and Ecology of the Mediterranean water shrew (Neomys anomalus Cabrera, 1907) in Belarus] // Ecological Sciences. Vol.2. No.1(24). P.122-125. [in Russian, with English summary]

Savarin A.A. 2019b. [Mediterranean water shrew (Neomys anomalus) in Belarus: return from oblivion.] Minsk: Kolorgrad. 27 p. [in Russian]

Savarin A.A. 2019c. [The find of the Mediterranean water shrew (Neomys anomalus Cabrera, 1907) in Ushachy district of Vitebsk region] // Vestnik VGU. No.2(103). P.66-71. [in Russian, with English summary]

Savarin A.A. 2020. [Water shrew (Neomys) of Belarus, sibling species.] Minsk: Kolorgrad. 28 p. [in Russian]

Selyunina Z.V. 2005. [Mammals of the region of the Black Sea biosphere reserve listed in the Red book of Ukraine (as of 2004)] // Oleksyk T.K. (ed.) [Scientific bulletin of the Uzhhorod university. Series biology. Vol.17.] Uzhhorod: Uzhhorod National University. P.86-88. [in Ukrainian]

Serzhanin I.N. 1961. [Mammals of Belarus.] Minsk: AS BSSR Publ. 318 p. [in Russian]

Serzhanin I.N., Serzhanin Yu.I., Slesarevich V.I. 1967. [Identification guide to the Mammals of the Belarus.] Minsk: "Nauka i technica". 120 p. [in Russian]

Shapovalov A.S. 2019. [Mediterranean water shrew Neomys anomalus Cabrera, 1907] // Prisniy Yu.A. (ed.) [Red Book of the Belgorod region. Rare and endangered plants, lichens, fungi and animals.] Belgorod: IC BelSU. P.602. [in Russian]

Shevchenko L.S. \& Zolotukhina S.I. 2005. [Mammals. Issue 2: Insectivores, Bats, Lagomorphs. National Museum of Natural History of Ukraine, Kyiv.] 238 p. [in Russian]

Sitnikova E.F. \& Mishta A.V. 2006. [Fauna of mammals of the Bryansk region: species composition, distribution, number] // Fedotov Yu.P. (eds.) [Study and protection of biological diversity of the Bryansk region. Materials for maintaining the Red Book of the Bryansk Region. Vol.2.] Trubchevsk: "Kirillitsa" Pabl. P.107-150. [in Russian]

Sitnikova E.F. \& Mishta A.V. 2008. [Mammals of the "Bryansk Forest" Nature Reserve] // [Fauna of vertebrates of the "Bryansk Forest" Nature Reserve (birds, mammals).] Bryansk: "Desyatochka". P.50-85. [in Russian]

Smirnov N.A. \& Skilsky I.V. 2010. [The terrestrial vertebrates mortality in the model area of the road in the plain part of Bukovina] // Fedotov Yu.P., Sitnikova E.F. (eds.) [Problems of Studying and Conservation of Wildlife in Natural and Anthropogenic Ecosystems: Proceedings of International Scientific Conference (Chernivtsi, 13 November 2009).] Chernivtsi: Druk-Art. P.116-118. [in Ukrainian]

Sokolov A.S. \& Lada G.A. 2007. [Mediterranean water shrew Neomys anomalus Cabrera, 1907] // [Vertebrates of the Tambov region: cadastre.] Tambov: "Yulis". P.215-216. [in Russian]

Sokur I.T. 1963. [New materials to the knowledge of the fauna of small mammals of Ukraine] // [Proceedings of the Zoological Museum (Kyiv)] No.32. P.29-42. [in Ukrainian]

Spitzenberger F. 1990. Gattung Neomys Kaup, 1829 // Niethammer J., Kapp F. (eds.). Handbuch der Saugetiere Europas. Band 3/1. Insektenfresser, Herrentiere. Wiesbaden: Aula-Verlag. P.317-333.

Tatarynov K.A. 1956. [Animals of the western regions of Ukraine. Ecology, significance, protection] Kyiv: AS URSR Publ. 188 p. [in Ukrainian]

Tokarskiy V.A. \& Zorya O.V. 2013. [Mediterranean water shrew Neomys anomalus (Cabrera, 1907)] // Tokarskiy V.A. (ed.) [Red Book of Kharkiv region. Animals.] Kharkiv: V.N. Karazin Kharkiv National University. P.374. [in Ukrainian]

Tovpinets N.N. \& Evstafiev I.L. 2005. Rare, Red Data Book and threatened species of terrestrial mammals of Ukraine on the territory of Crimea: past, present, future. Issue 2 . Rodents, carnivores // Reserves of the Crimea: Materials of the III scientific conference (April 22, 2005). Simferopol: KRA "Ecology and World". Vol.2. P.184-189. [in Russian]

Tsvelykh O.M. 2018. [New finds of Mediterranean water shrew Neomys anomalus Cabrera near Kiyv] // Akimov I.A. et al. (eds.) [Series: "Conservation Biology in Ukraine". Vol.2. No.7.] Kyiv: Schmalhausen Institute of Zoology of NASc Ukraine. P.347. [in Ukrainian]

Turov S.S. 1955. [Preliminary remarks on the fauna of mammals of Belovezhskaya Pushcha] // [Scientific notes of the Moscow City Pedagogical Institute. V.P. Potemkin.] Vol.38. P.5-12. [in Russian]

Ushakov M.V. 2009. [Mediterranean water shrew Neomys anomalus Cabrera, 1907] // Sarychev V.S. (ed.) [Vertebrates of the Lipetsk region. Cadastre.] Voronezh: VSU. P.392. [in Russian]

Zagorodnyuk I.V., Pokynchereda V.F., Kyselyuk O.I. \& Dovganych Y.A. 1997. [Theriofauna of the Carpathian Biosphere Reserve] // Vestnik zoologii. Suppl. No.5. 60 p. [in Ukrainian]

Zaitsev M.V., Voyta L.L. \& Sheftel B.I. 2014. [The mammals of Russia and adjacent territories. Lipotyphlans.] Saint-Petersburg: Nauka. 391 p. [in Russian, with English summary]

Zaitseva H. \& Gnatina O. 2010. The feeding relationships of tawny owl (Strix aluco L.) and micromammals on the territory of Chernigivske Polissya // Visnyk of Lviv university. Biology series. No.54. P.132-137. [in Ukrainian, with English summary]

Zatushevskyy A.T., Shydlovskyy I.V., Zakala O.S., Dykyy I.V., Holovachov O.V., Senyk M.A. \& Romanova Kh.J. 2010. 
[Catalogue of the mammals collection of the Zoological museum of Ivan Franko national university of Lviv.] Lviv: LNU Publ. 442 p. [in Ukrainian]

Zherdeva S.V. 2017. [Mediterranean water shrew Neomys anomalus Cabrera, 1907] // Konechnaya G.Yu. et al. (eds.) [Red Book of the Kursk region: rare and endangered species of animals, plants and fungi.] Kaliningrad; Kursk: ID ROST-DOAFK. P.127. [in Russian]
Zherdeva S.V., Bausov I.A., Poluyanov A.V. \& Sakhatskaya T.V. 2009. [Rare and endangered species of animals and plants of the Kursk region.] Kursk: IC KSU. 236 p. [in Russian].

Zorya A.V. 2008. [The first find of the Mediterranean water shrew (Neomys anomalus) in the Kharkov region] // Vestnik Zoologii. Vol.42. No.5. P.476. [in Russian]

Appendix 1. Checklist of occurrence localities of Neomys anomalus in Lithuania, Belarus, Ukraine and Russia. Localities included in the spatial analysis are marked with *; localities filtered out during spatial aggregations removal are marked with $* *$; localities from the territory that suffered from anthropogenic transformation during the time passed from the date of capture or obtained from pellets analysis are marked with ***.

ZM NUK - Zoological museum of Taras Shevchenko National University of Kyiv; NMNH (Kyiv) — National Museum of Natural History at the National Academy of Sciences of Ukraine; IZAN - collection of the Department of Monitoring and Animal Conservation, Schmalhausen Institute of Zoology, Kyiv; ZMMU — Zoological Museum of Moscow State University; ZIN RAS - Zoological Institute of Russian Academy of Sciences; ZM PSU — Zoological museum of Penza State University; SMNH (Lviv) - State Museum of Natural History NAS of Ukraine (Lviv); ZM UzhNU - Zoological museum of Uzhhorod National University; ZM LNU — Ivan Franko National University of Lviv; rusmam — Portal "Mammals of Russia" (http://rusmam.ru/)

\begin{tabular}{|c|c|c|c|c|c|}
\hline Place & Longitude & Latitude & Date & Reference & \\
\hline $\begin{array}{l}\text { Belgorod Region, Belogorye Zapovednik, } \\
\text { "Yamskaya steppe" area, gully of Sura River }\end{array}$ & 37.6363 & 51.2035 & 22.06 .2007 & Shapovalov, 2019 & $*$ \\
\hline $\begin{array}{l}\text { Belgorod Region, vicinity of Belgorod, floodplain } \\
\text { of Seversky Donets River }\end{array}$ & 36.6207 & 50.5586 & 31.08 .1926 & ZMMU & $*$ \\
\hline $\begin{array}{l}\text { Bryansk Region, Komarichsky District, vicinity } \\
\text { of Lagerevka Village, sandbar of Usozha River }\end{array}$ & 34.3892 & 52.414 & 23.07.2004 & $\begin{array}{l}\text { Mishta, 2005; Sitnikova \& } \\
\text { Mishta, 2006, } 2008\end{array}$ & $*$ \\
\hline $\begin{array}{l}\text { Bryansk Region, Suzemsky District, Bryanskiy } \\
\text { Les Zapovednik, quarter } 111\end{array}$ & 33.8797 & 52.4429 & 18.07.2003 & $\begin{array}{l}\text { Mishta, 2005; Sitnikova \& } \\
\text { Mishta, 2006, } 2008\end{array}$ & $* *$ \\
\hline $\begin{array}{l}\text { Bryansk Region, Suzemsky District, Bryanskiy } \\
\text { Les Zapovednik, quarter } 111\end{array}$ & 33.8776 & 52.4417 & 01.01 .2004 & $\begin{array}{l}\text { Mishta, 2005; Sitnikova \& } \\
\text { Mishta, 2006, } 2008\end{array}$ & $* *$ \\
\hline $\begin{array}{l}\text { Bryansk Region, Suzemsky District, Bryanskiy } \\
\text { Les Zapovednik, vicinity of Chukhrai }\end{array}$ & 33.8608 & 52.4623 & 13.06 .2004 & $\begin{array}{l}\text { Mishta, 2005; Sitnikova \& } \\
\text { Mishta, 2006, } 2008\end{array}$ & $*$ \\
\hline $\begin{array}{l}\text { Bryansk Region, Suzemsky District, Bryanskiy } \\
\text { Les Zapovednik, vicinity of Chukhrai }\end{array}$ & 33.8617 & 52.4625 & 01.06 .2005 & Mishta, 2005 & $* *$ \\
\hline $\begin{array}{l}\text { Bryansk Region, Suzemsky District, Natural } \\
\text { monument "Nerusso-Sevny" }\end{array}$ & 34.126 & 52.3973 & 01.01 .2005 & $\begin{array}{l}\text { Mishta, 2005; Sitnikova \& } \\
\text { Mishta, } 2006\end{array}$ & $* *$ \\
\hline $\begin{array}{l}\text { Bryansk Region, Trubchevsk District, Bryanskiy } \\
\text { Les Zapovednik, vicinity of Proletarsky cordon }\end{array}$ & 34.0555 & 52.5385 & 06.10 .2004 & $\begin{array}{l}\text { Mishta, 2005; Sitnikova \& } \\
\text { Mishta, 2006, } 2008\end{array}$ & $*$ \\
\hline $\begin{array}{l}\text { Bryansk Region, Trubchevsky District, Bryanskiy } \\
\text { Les Zapovednik, vicinity of Staroe Yamnoe } \\
\text { cordon }\end{array}$ & 33.8664 & 52.4497 & 01.07 .2007 & IZAN & $* *$ \\
\hline $\begin{array}{l}\text { Kaluga Region, Dzerzhinsky District, Ugra } \\
\text { National Park, Galkinskoe Forestry }\end{array}$ & 35.805 & 54.7144 & 01.06 .2004 & Alekseev et al., 2006 & $*$ \\
\hline $\begin{array}{l}\text { Kaluga Region, Dzerzhinsky District, Ugra } \\
\text { National Park, vicinity of Sabelnikovo Village }\end{array}$ & 35.9396 & 54.6616 & 27.06 .2004 & Alekseev et al., 2006 & $* *$ \\
\hline $\begin{array}{l}\text { Kaluga Region, Dzerzhinsky District, Ugra } \\
\text { National Park, vicinity of Sabelnikovo Village }\end{array}$ & 35.9396 & 54.6616 & 27.06 .2005 & Alekseev et al., 2006 & $* *$ \\
\hline $\begin{array}{l}\text { Kaluga Region, Ferzikovsky District, } 13 \mathrm{~km} \\
\text { South of Ferziko Village, Mshakovka ravine }\end{array}$ & 36.5763 & 54.4492 & 15.07 .2014 & Alekseev S.K. & $*$ \\
\hline $\begin{array}{l}\text { Kaluga Region, Khvastovichsky District, Natural } \\
\text { monument "Vytebet River and its floodplain" }\end{array}$ & 35.5597 & 53.4611 & 01.06 .2011 & Koryavchenkov, 2017 & $* *$ \\
\hline $\begin{array}{l}\text { Kaluga Region, Khvastovichsky District, Natural } \\
\text { monument "Green zone of Khvastovichsky } \\
\text { settlement" }\end{array}$ & 35.0654 & 53.4835 & 01.06 .2011 & Koryavchenkov, 2017 & $* *$ \\
\hline $\begin{array}{l}\text { Kaluga Region, Khvastovichsky District, Natural } \\
\text { monument "Lovotyanka River and its floodplain" }\end{array}$ & 35.0867 & 53.6231 & 01.06 .2011 & Koryavchenkov, 2017 & $*$ \\
\hline
\end{tabular}


Appendix 1 (continued)

\begin{tabular}{|c|c|c|c|c|c|}
\hline Place & Longitude & Latitude & Date & Reference & \\
\hline $\begin{array}{l}\text { Kaluga Region, Khvastovichsky District, Natural } \\
\text { monument "Obelnya River and its floodplain" }\end{array}$ & 35.1307 & 53.2997 & 01.06 .2011 & Koryavchenkov, 2017 & $*$ \\
\hline $\begin{array}{l}\text { Kaluga Region, Kozeksk District, Ugra National } \\
\text { Park, Berezichsky Forestry }\end{array}$ & 35.8558 & 53.9567 & 01.06 .2004 & $\begin{array}{l}\text { Alekseev \& Rogulenko, } \\
2014\end{array}$ & $* *$ \\
\hline $\begin{array}{l}\text { Kaluga Region, Ulyanovsky District, Kaluzhskiye } \\
\text { Zaseki Zapovednik }\end{array}$ & 35.739 & 53.568 & 01.06 .2004 & Koryavchenkov, 2017 & $*$ \\
\hline $\begin{array}{l}\text { Kaluga Region, Yukhnovsky District, Ugra } \\
\text { National Park, Belyaevsky Forestry }\end{array}$ & 35.0851 & 54.8036 & 01.06 .2004 & $\begin{array}{l}\text { Alekseev \& Rogulenko, } \\
2014\end{array}$ & $* *$ \\
\hline $\begin{array}{l}\text { Kaluga Region, Yukhnovsky District, Ugra } \\
\text { National Park, Ugra Forestry }\end{array}$ & 35.0405 & 54.7682 & 01.06 .2004 & Koryavchenkov, 2017 & $*$ \\
\hline $\begin{array}{l}\text { Kursk Region, Dmitriyevsky District, Pershino } \\
\text { biological station }\end{array}$ & 35.1317 & 52.1022 & 08.08 .1926 & ZMMU & $* *$ \\
\hline $\begin{array}{l}\text { Kursk Region, Dmitriyevsky District, Pershino } \\
\text { biological station }\end{array}$ & 35.1317 & 52.1022 & 17.09.1926 & ZMMU & $* *$ \\
\hline $\begin{array}{l}\text { Kursk Region, Dmitriyevsky District, Pershino } \\
\text { biological station }\end{array}$ & 35.1268 & 52.1041 & 15.08 .1927 & ZMMU & $* *$ \\
\hline $\begin{array}{l}\text { Kursk Region, Dmitriyevsky District, Pershino } \\
\text { biological station }\end{array}$ & 35.1317 & 52.1022 & 18.08 .1927 & ZMMU & $* *$ \\
\hline $\begin{array}{l}\text { Kursk Region, Dmitriyevsky District, Pershino } \\
\text { biological station }\end{array}$ & 35.1317 & 52.1022 & 19.08.1927 & ZMMU & $* *$ \\
\hline $\begin{array}{l}\text { Kursk Region, Dmitriyevsky District, vicinity } \\
\text { of Rogozna Village }\end{array}$ & 35.0878 & 52.0817 & 17.08.1927 & ZMMU & $* *$ \\
\hline $\begin{array}{l}\text { Kursk Region, Dmitriyevsky District, vicinity } \\
\text { of Snizha Village }\end{array}$ & 35.1711 & 52.1281 & 16.08 .1927 & ZMMU & * \\
\hline Kursk Region, Kursky District, Linevo Lake & 36.2445 & 51.7104 & 06.06 .2006 & Zherdeva, 2017 & $*$ \\
\hline $\begin{array}{l}\text { Kursk Region, Sudzhansky District, vicinity } \\
\text { of Sudzha }\end{array}$ & 35.2926 & 51.2009 & 28.08 .1926 & ZMMU & $*$ \\
\hline Kursk Region, vicinity of Dmitriyev & 35.0921 & 52.1229 & 25.07 .1927 & ZMMU & $* *$ \\
\hline Kursk Region, vicinity of Dmitriyev & 35.0873 & 52.122 & 27.07 .1927 & ZMMU & $* *$ \\
\hline Kursk Region, vicinity of Lgov & 35.2479 & 51.6726 & 03.09 .1926 & ZMMU & $*$ \\
\hline $\begin{array}{l}\text { Mordovia, Temnikov District, Mordovski } \\
\text { Zapovednik, "Inorka" area }\end{array}$ & 43.1289 & 54.729 & 03.09 .1936 & Borodin, 2013 & $* *$ \\
\hline $\begin{array}{l}\text { Mordovia, Temnikov District, Mordovski } \\
\text { Zapovednik, quarter } 358\end{array}$ & 43.1887 & 54.7652 & 01.01 .2013 & Ruchin et al., 2018 & $*$ \\
\hline $\begin{array}{l}\text { Mordovia, Temnikov District, Mordovski } \\
\text { Zapovednik, quarter } 358\end{array}$ & 43.1887 & 54.7652 & 01.01 .2013 & Ruchin et al., 2018 & $* *$ \\
\hline $\begin{array}{l}\text { Mordovia, Temnikov District, Mordovski } \\
\text { Zapovednik, quarter } 377\end{array}$ & 43.1015 & 54.7542 & 29.08 .1979 & Borodin, 2013 & ** \\
\hline $\begin{array}{l}\text { Mordovia, Temnikov District, Mordovski } \\
\text { Zapovednik, quarter } 408\end{array}$ & 43.2011 & 54.7487 & 01.01 .2013 & Ruchin et al., 2018 & ** \\
\hline $\begin{array}{l}\text { Mordovia, Temnikov District, Mordovski } \\
\text { Zapovednik, quarter } 449\end{array}$ & 43.2197 & 54.7111 & 29.04 .1975 & Borodin, 2013 & ** \\
\hline $\begin{array}{l}\text { Penza Region, Zemetchinsky District, vicinity } \\
\text { of Aleksandrovka }\end{array}$ & 42.2019 & 53.6804 & 02.08 .1993 & ZM PSU & $* *$ \\
\hline $\begin{array}{l}\text { Penza Region, Zemetchinsky District, vicinity } \\
\text { of Aleksandrovka }\end{array}$ & 42.2019 & 53.6804 & 11.08.1997 & ZM PSU & $*$ \\
\hline $\begin{array}{l}\text { Tambov Region, vicinity of Tambov, Prigorodnoe } \\
\text { Forestry, northwest of Vlasovskoe peatland }\end{array}$ & 41.5267 & 52.7216 & 22.04 .1982 & Lada \& Sokolov, 2000 & $*$ \\
\hline $\begin{array}{l}\text { Voronezh Region, Usmansky Bor, South-Western } \\
\text { outskirts, vicinity Biological Educational and } \\
\text { Scientific Center of Voronezh State University } \\
\text { "Venevitinovo" Samara Swamp }\end{array}$ & 39.384 & 51.8111 & 01.07 .1991 & Klimov, 2011 & $*$ \\
\hline $\begin{array}{l}\text { Voronezh Region, Verkhnekhavsky District, } \\
\text { vicinity of Belovka Village. }\end{array}$ & 39.7934 & 51.8999 & 25.07 .2014 & $\begin{array}{l}\text { Sapelnikov \& } \\
\text { Sapelnikova, } 2015 \\
\end{array}$ & $*$ \\
\hline Crimea, Alma River & 34.2671 & 44.668 & 03.05 .1935 & ZMMU & $* *$ \\
\hline $\begin{array}{l}\text { Crimea, Bakhchysarai District, Prokhladnoe } \\
\text { Village }\end{array}$ & 33.9925 & 44.7461 & 25.07 .1987 & rusmam.ru & $* *$ \\
\hline
\end{tabular}


Appendix 1 (continued)

\begin{tabular}{|c|c|c|c|c|c|}
\hline Place & Longitude & Latitude & Date & Reference & \\
\hline $\begin{array}{l}\text { Crimea, Bakhchysarai District, Shelkovichnoe } \\
\text { Village }\end{array}$ & 34.1011 & 44.635 & 15.10 .1999 & rusmam.ru & $* *$ \\
\hline $\begin{array}{l}\text { Crimea, Bakhchysarai District, Shelkovichnoe } \\
\text { Village }\end{array}$ & 34.1011 & 44.635 & 15.10 .1999 & rusmam.ru & $* *$ \\
\hline $\begin{array}{l}\text { Crimea, Bakhchysarai District, Trudolubovka } \\
\text { Village }\end{array}$ & 33.9914 & 44.7739 & 15.09 .1998 & rusmam.ru & $* *$ \\
\hline $\begin{array}{l}\text { Crimea, Bakhchysarai District, Trudolubovka } \\
\text { Village }\end{array}$ & 33.9914 & 44.7739 & 15.09.1998 & rusmam.ru & $* *$ \\
\hline Crimea, Bakhchysarai District, Zalesnoe Village & 33.7789 & 44.5786 & 15.11.2008 & ZM NUK & $*$ \\
\hline $\begin{array}{l}\text { Crimea, Beshuyskoe Forestry, Kholodnaya Voda } \\
\text { Tract, vicinity of Chatyr-Dag }\end{array}$ & 34.2007 & 44.7149 & 08.09 .1918 & ZIN RAS & $* *$ \\
\hline Crimea, Bolshaya Chuchel Mountain & 34.1618 & 44.6568 & 16.07 .1967 & SMNH (Lviv) & $* *$ \\
\hline Crimea, Crimean Zapovednik and Hunting Farm & 34.2697 & 44.664 & 16.08 .1936 & ZMMU & $* *$ \\
\hline $\begin{array}{l}\text { Crimea, Crimean Zapovednik and Hunting Farm, } \\
\text { Kacha River }\end{array}$ & 34.0117 & 44.66 & 27.08 .1969 & \begin{tabular}{|l|} 
Shevchenko \& \\
Zolotukhina, 2005 \\
\end{tabular} & ** \\
\hline Crimea, Crimean Zapovednik, Alabach cordon & 34.22 & 44.6177 & 16.07.1975 & \begin{tabular}{|l|} 
Shevchenko \& \\
Zolotukhina, 2005 \\
\end{tabular} & $* *$ \\
\hline $\begin{array}{l}\text { Crimea, Crimean Zapovednik, Bazarchik place, } \\
\text { Alma River (now Pochtovoe) }\end{array}$ & 33.942 & 44.8373 & 20.10 .1923 & ZMMU & $* *$ \\
\hline Crimea, Crimean Zapovednik, Chernaya River & 34.2717 & 44.6935 & 27.06 .1975 & \begin{tabular}{|l|} 
Shevchenko \& \\
Zolotukhina, 2005
\end{tabular} & $* *$ \\
\hline $\begin{array}{l}\text { Crimea, Crimean Zapovednik, Kholodnaya Voda } \\
\text { Tract, Alma River }\end{array}$ & 34.2007 & 44.7149 & 16.10 .1923 & ZMMU & $* *$ \\
\hline $\begin{array}{l}\text { Crimea, Crimean Zapovednik, mouth } \\
\text { of Savlyk-Su River }\end{array}$ & 34.2697 & 44.664 & 11.10 .1973 & \begin{tabular}{|l|} 
Shevchenko \& \\
Zolotukhina, 2005 \\
\end{tabular} & $* *$ \\
\hline Crimea, Crimean Zapovednik, Sodovy cordon & 34.3017 & 44.6959 & 28.10 .1967 & \begin{tabular}{|l|} 
Shevchenko \& \\
Zolotukhina, 2005 \\
\end{tabular} & $* *$ \\
\hline $\begin{array}{l}\text { Crimea, Crimean Zapovednik, source } \\
\text { of Kachi River }\end{array}$ & 34.2367 & 44.6315 & 24.04.1967 & ZMMU & $* *$ \\
\hline $\begin{array}{l}\text { Crimea, Greater Yalta District, Krasnokamenka } \\
\text { Village }\end{array}$ & 34.2931 & 44.5703 & 25.10 .1985 & rusmam.ru & ** \\
\hline Crimea, Kurortnoe Village & 35.18 & 44.92 & 09.1973 & ZM NUK & $* * *$ \\
\hline Crimea, Kuybyshevsky District, Sokolinoe Village & 33.9576 & 44.5543 & 20.06.1957 & $\begin{array}{l}\text { Shevchenko \& } \\
\text { Zolotukhina, } 2005\end{array}$ & $* *$ \\
\hline Crimea, Nikita Village & 34.2285 & 44.514 & 03.06 .1979 & \begin{tabular}{|l|} 
Shevchenko \& \\
Zolotukhina, 2005 \\
\end{tabular} & $* *$ \\
\hline $\begin{array}{l}\text { Crimea, rock outcrops at foot of mount } \\
\text { Syuryu-Kaya, Bank of Sara-Uzen River }\end{array}$ & 33.9683 & 44.5104 & 01.01 .1983 & \begin{tabular}{|l} 
Tovpinets \& Evstafiev, \\
2005
\end{tabular} & $* *$ \\
\hline Crimea, Simferopol District, Perevalnoe Village & 34.2924 & 44.8365 & 01.01 .2007 & $\begin{array}{l}\text { Tovpinets \& Evstafiev, } \\
2005\end{array}$ & $* *$ \\
\hline Crimea, Simferopol District, Perevalnoe Village & 34.3117 & 44.9114 & 15.09 .1998 & rusmam.ru & $* *$ \\
\hline Crimea, Simferopol District, Perevalnoe Village & 34.3383 & 44.7778 & 05.04 .1999 & rusmam.ru & $* *$ \\
\hline Crimea, Sudaksky District, Shchebetovka Village & 35.1356 & 44.9242 & 25.09 .1998 & \begin{tabular}{|l|} 
Tovpinets \& Evstafiev, \\
2005
\end{tabular} & $*$ \\
\hline Crimea, vicinity of Grand Canyon & 34.0028 & 44.5226 & 08.06 .1986 & Dulitsky, 2001 & $* *$ \\
\hline Crimea, vicinity of Krasnolesye Village & 34.2357 & 44.811 & 02.07 .2009 & Mishta, 2008 & $*$ \\
\hline Cherkasy Region, Kozatskoe & 31.1469 & 49.1 & $1926-1928$ & Pidoplichko, 1932 & $* * *$ \\
\hline Cherkasy Region, Mliev Village, Vilshanka River & 31.4879 & 49.3141 & $\begin{array}{c}06.1926 \\
30.07 .1927\end{array}$ & Pidoplichko, 1932 & *** \\
\hline Cherkasy Region, Moshny District, Irdyn Swamp & 31.7084 & 49.4033 & 01.07 .1927 & Pidoplichko, 1932 & $* * *$ \\
\hline Cherkasy Region, Uman & 30.1752 & 48.7206 & 1925 & Pidoplichko, 1929 & $* * *$ \\
\hline Cherkasy Region, vicinity of Katerynopil & 30.9704 & 48.9294 & 22.08 .1928 & Pidoplichko, 1932 & $* * *$ \\
\hline Cherkasy Region, vicinity of Katerynopol & 30.9806 & 48.9595 & 01.01 .1928 & NMNH (Kyiv) & $*$ \\
\hline $\begin{array}{l}\text { Cherkasy Region, vicinity of Yablunivka, } \\
\text { Ros River }\end{array}$ & 31.2635 & 49.4086 & 09.05 .1926 & Pidoplichko, 1932 & $* * *$ \\
\hline
\end{tabular}


Appendix 1 (continued)

\begin{tabular}{|c|c|c|c|c|c|}
\hline Place & Longitude & Latitude & Date & Reference & \\
\hline $\begin{array}{l}\text { Cherkasy Region, Zvenyhorodka District, } \\
\text { Kozatskoe }\end{array}$ & 31.1469 & 49.1006 & 17.11.1930 & Pidoplichko, 1937 & $* * *$ \\
\hline $\begin{array}{l}\text { Chernivitsi Region, vicinity of Lenkovtsy, Sursha } \\
\text { River }\end{array}$ & 26.7854 & 48.5237 & 02.05 .2018 & Gkhazali M. (UKRBIN) & $*$ \\
\hline Chernivtsi Region, Khotyn District, Klishkovtsy & 26.2925 & 48.4535 & 25.05 .1950 & Sokur, 1963 & $* * *$ \\
\hline $\begin{array}{l}\text { Chernivtsi Region, on road between Kitsman and } \\
\text { Dubovtsy }\end{array}$ & 25.7204 & 48.3893 & 01.01 .2009 & Smirnov \& Skilskiy, 2010 & $*$ \\
\hline Chernivtsi Region, Sadhora District, Toporivtsi & 26.0752 & 48.3741 & 31.05 .1950 & Sokur, 1963 & $* *$ \\
\hline $\begin{array}{l}\text { Dnepropetrovsk Region, vicinity of Kryvyi Rih, } \\
\text { Northern Red gully Landscape Reserve }\end{array}$ & 33.5131 & 48.1051 & 02.10 .2017 & Sevidov V. (UKRBIN) & $*$ \\
\hline $\begin{array}{l}\text { Ivano-Frankivsk Region, Carpathian National } \\
\text { Nature Park }\end{array}$ & 24.5018 & 48.3909 & 1986-1999 & Kyselyuk, 2002 & $* * *$ \\
\hline Ivano-Frankivsk Region, Dniester River Bank & 24.7534 & 49.1119 & 28.06 .1959 & SMNH (Lviv) & $*$ \\
\hline Ivano-Frankivsk Region, Galich & 24.7451 & 49.1154 & 10.06 .1950 & Sokur, 1963 & $* * *$ \\
\hline Ivano-Frankivsk Region, Gorodenka & 25.4824 & 48.6772 & 15.06 .1950 & Sokur, 1963 & $*$ \\
\hline Ivano-Frankivsk Region, Kolomya & 25.0374 & 48.5387 & 01.06 .1950 & Sokur, 1963 & $* * *$ \\
\hline $\begin{array}{l}\text { Ivano-Frankivsk Region, Nadvirna District, } \\
\text { Polonyna Pozhizhevskaja }\end{array}$ & 24.5327 & 48.156 & 30.07 .1958 & SMNH (Lviv) & $* *$ \\
\hline $\begin{array}{l}\text { Ivano-Frankivsk Region, Nadvirna District, } \\
\text { Rogatin }\end{array}$ & 24.6201 & 49.41 & 21.06 .1950 & Sokur, 1963 & $* *$ \\
\hline $\begin{array}{l}\text { Ivano-Frankivsk Region, Nadvirna District, } \\
\text { Zabolotov }\end{array}$ & 25.292 & 48.4747 & 03.06 .1950 & Sokur, 1963 & $* *$ \\
\hline $\begin{array}{l}\text { Kharkov Region, Volchansk District, Verkhniy } \\
\text { Saltov Village }\end{array}$ & 36.791 & 50.1057 & 01.01 .2005 & Zorya, 2008 & $*$ \\
\hline $\begin{array}{l}\text { Kherson Region, Bilozerka District, Kizomys } \\
\text { Village, Bobrovka Lake }\end{array}$ & 32.5558 & 46.5448 & 02.11 .2005 & NMNH & $* *$ \\
\hline $\begin{array}{l}\text { Kherson Region, Hola Prystan, Danube overflow } \\
\text { land }\end{array}$ & 32.5221 & 46.5394 & 10.07.1996 & Mishta, 2008 & $* *$ \\
\hline $\begin{array}{l}\text { Kherson Region, Hola Prystan District, } 7 \text { km } \\
\text { South-East of Malye Kopani Village, Burkuty } \\
\text { Tract }\end{array}$ & 32.7748 & 46.4047 & 01.01 .1967 & Abelentsev, 1967 & $*$ \\
\hline $\begin{array}{l}\text { Kherson Region, Hola Prystan District, } 7 \mathrm{~km} \\
\text { South-East of Malye Kopani Village, Burkuty } \\
\text { Tract }\end{array}$ & 32.777 & 46.4046 & 1967 & Abelentsev, 1967 & $* * *$ \\
\hline $\begin{array}{l}\text { Kherson Region, Hola Prystan District, vicinity } \\
\text { of Hola Prystan }\end{array}$ & 32.5003 & 46.5328 & 13.11.1963 & Abelentsev, 1967 & $* *$ \\
\hline $\begin{array}{l}\text { Kherson Region, Hola Prystan District, West side } \\
\text { of Black Sea Biosphere Reserve }\end{array}$ & 32.1464 & 46.4692 & 01.01 .1967 & Gizenko, 1967 & $* *$ \\
\hline $\begin{array}{l}\text { Kherson Region, vicinity of Gopri, Bobrovka } \\
\text { Lake }\end{array}$ & 32.5487 & 46.5425 & 01.01 .1963 & NMNH & $*$ \\
\hline Khmelnitsky Region, Derazhnia District, Kalnya & 27.5394 & 49.27 & 1928 & Pidoplichko, 1932 & $* * *$ \\
\hline Khmelnitsky Region, Izyzslav & 26.8254 & 50.1174 & 8.06 .1949 & Sokur, 1963 & $* * *$ \\
\hline Khmelnitsky Region, Kamianets-Podilskyi & 26.5789 & 48.679 & 12.05 .1952 & Sokur, 1963 & $* *$ \\
\hline $\begin{array}{l}\text { Khmelnitsky Region, Kamianets-Podilskyi } \\
\text { District, Kulchievtsy Village }\end{array}$ & 26.7297 & 48.6534 & 14.08.2004 & Mishta, 2008 & $* * *$ \\
\hline Khmelnitsky Region, Krasilov & 26.9691 & 49.6488 & 29.07 .1929 & Pidoplichko, 1937 & $*$ \\
\hline Khmelnitsky Region, Starokonstantinov & 27.253 & 49.7669 & 10.08 .1928 & Pidoplichko, 1937 & $* * *$ \\
\hline $\begin{array}{l}\text { Khmelnitsky Region, vicinity of Kamianets- } \\
\text { Podilskyi, Muksha River }\end{array}$ & 26.6013 & 48.713 & 25.09 .1927 & Pidoplichko, 1932 & $* * *$ \\
\hline Kirovohrad Region, Kirovohrad (Kropyvnytsky) & 32.2355 & 48.5518 & 1928 & NMNH (Kyiv) & $* * *$ \\
\hline $\begin{array}{l}\text { Kyiv, Kyiv-Sviatoshyn District, left Bank } \\
\text { of Lubka River }\end{array}$ & 30.3006 & 50.4981 & 10.07 .2017 & Tsvelykh, 2018 & $* *$ \\
\hline Kyiv Region, Koncha Zaspa reserve & 30.5683 & 50.2994 & $\begin{array}{c}03.10 .1930- \\
25.06 .1931\end{array}$ & $\begin{array}{l}\text { Isotiv, 1932; Popov, 1932; } \\
\text { Sharleman, } 1933\end{array}$ & $* * *$ \\
\hline
\end{tabular}


Appendix 1 (continued)

\begin{tabular}{|c|c|c|c|c|c|}
\hline Place & Longitude & Latitude & Date & Reference & \\
\hline Kyiv Region, Bila Tserkva District, Shkvarivka & 30.1847 & 49.7412 & 26.06 .1927 & Pidoplichko, 1932 & $* * *$ \\
\hline Kyiv Region, Bila Tserkva, Ros River & 30.0576 & 49.803 & 25.06 .1927 & Pidoplichko, 1932 & $* * *$ \\
\hline Kyiv Region, Boryspil District, Bortnishi & 30.7304 & 50.3885 & 27.10 .1957 & ZM NUK & $* *$ \\
\hline $\begin{array}{l}\text { Kyiv Region, former Berezansky District (now } \\
\text { Yagotinsky District), Supoy River }\end{array}$ & 31.758 & 50.238 & 01.01 .1956 & \begin{tabular}{|l|} 
Abelentsev \& \\
Pidoplichko, 1956 \\
\end{tabular} & $*$ \\
\hline $\begin{array}{l}\text { Kyiv Region, Kyiv, Holosiivsky District, Pirogovo } \\
\text { urban residential }\end{array}$ & 30.5087 & 50.3466 & 10.03.1988 & Tsvelykh, 2018 & $* *$ \\
\hline $\begin{array}{l}\text { Kyiv Region, Kyiv-Sviatoshyn District, } \\
\text { Holosiivskyi National Nature Park }\end{array}$ & 30.5585 & 50.2818 & 03.10 .2009 & Mishta et al., 2018 & ** \\
\hline $\begin{array}{l}\text { Kyiv Region, Kyiv-Sviatoshyn District, } \\
\text { Lesniki Tract }\end{array}$ & 30.55 & 50.2801 & 28.09 .2005 & Mishta, 2008 & $*$ \\
\hline $\begin{array}{l}\text { Kyiv Region, Kyiv-Sviatoshyn District, } \\
\text { vicinity of Kruglik Village }\end{array}$ & 30.4382 & 50.3027 & 01.10 .2005 & Mishta, 2008 & $* *$ \\
\hline $\begin{array}{l}\text { Kyiv Region, Kyiv-Sviatoshyn District, } \\
\text { vicinity of Podgortsy railway station }\end{array}$ & 30.5533 & 50.2703 & 16.11 .2004 & Mishta, 2008 & ** \\
\hline $\begin{array}{l}\text { Kyiv Region, Kyiv-Sviatoshyn District., } \\
\text { Romanovskoe swamp, Bank of Lubka River }\end{array}$ & 30.2718 & 50.5015 & 10.07.2017 & Tsvelykh, 2018 & ** \\
\hline Kyiv Region, Obolon & 30.5211 & 50.5298 & 19.10.1963 & ZM NUK & $* *$ \\
\hline $\begin{array}{l}\text { Kyiv Region, Obukhiv District, between Villages } \\
\text { of Krenychi and Gvozdov }\end{array}$ & 30.501 & 50.242 & 01.04 .2014 & Mishta et al., 2018 & $* *$ \\
\hline $\begin{array}{l}\text { Kyiv Region, Obukhiv District, between Villages } \\
\text { of Krenychi and Gvozdov }\end{array}$ & 30.5029 & 50.2459 & 01.04 .2015 & Mishta et al., 2018 & $* *$ \\
\hline Kyiv Region, Shpitky Village & 30.144 & 50.4129 & 25.08 .1929 & Pidoplichko, 1937 & $* * *$ \\
\hline Kyiv Region, Zhukov Island & 30.5687 & 50.3601 & 01.01 .1937 & Pidoplichko, 1937 & $* *$ \\
\hline $\begin{array}{l}\text { Lugansk Region, Kremenskoy District, } \\
\text { Serebryansky Forestry, floodplain of Seversky } \\
\text { Donets, Chernikova Lake }\end{array}$ & 38.1316 & 48.9457 & 01.01 .1961 & $\begin{array}{l}\text { Abelentsev, 1966; } \\
\text { Abelentsev \& } \\
\text { Pidoplichko, } 1967 \\
\end{array}$ & $*$ \\
\hline Lviv Region, Drohobych District, Gai & 24.2625 & 49.7557 & 29.06 .1950 & Sokur, 1963 & $* *$ \\
\hline $\begin{array}{l}\text { Lviv Region, Glinyansky District, Yasenevka } \\
\text { Village }\end{array}$ & 24.8163 & 49.8184 & 01.11 .1951 & Tatarynov, 1956; ZM LNU & $*$ \\
\hline Lviv Region, Gorodok & 23.6505 & 49.7812 & 07.07 .1950 & Sokur, 1963 & $* *$ \\
\hline Lviv Region, Ivano-Frankivsk & 23.7436 & 49.9008 & 07.07 .1948 & Sokur, 1963 & ** \\
\hline Lviv Region, Khodorov & 24.3225 & 49.4145 & 24.05 .1950 & Sokur, 1963 & $* * *$ \\
\hline Lviv Region, Kimets Village & 23.1766 & 48.8346 & 01.01 .1960 & ZM LNU & $* *$ \\
\hline Lviv Region, Lisinichi Village, vicinity of Lviv & 24.1089 & 49.8339 & 01.01 .1957 & SMNH (Lviv) & $* *$ \\
\hline Lviv Region, Nesterovo (Zhovkva) & 23.9676 & 50.0534 & 08.07 .1950 & Sokur, 1963 & $* *$ \\
\hline Lviv Region, Pomoryany & 24.939 & 49.6396 & 09.07 .1950 & Sokur, 1963 & $* *$ \\
\hline $\begin{array}{l}\text { Lviv Region, Pustomytovsky District, Davydov } \\
\text { Village }\end{array}$ & 24.1195 & 49.7533 & 27.07.1956 & SMNH (Lviv) & * \\
\hline Lviv Region, Roztochchia Biosphere Reserve & 23.6575 & 49.9642 & 01.01 .2004 & Kyjko et al., 2005 & $* *$ \\
\hline $\begin{array}{l}\text { Lviv Region, Strelkovsky District, } \\
\text { (Staryi Sambir District now), Verkhny Luzhok }\end{array}$ & 23.0212 & 49.3678 & 5.08 .1950 & Sokur, 1963 & $* * *$ \\
\hline Lviv Region, Turka District, Volche Village & 22.8626 & 49.2268 & 30.07 .1959 & SMNH (Lviv) & $* * *$ \\
\hline Lviv Region, Turka Village & 23.0366 & 49.1443 & 5.07 .1950 & Sokur, 1963 & $* * *$ \\
\hline Lviv Region, Zolochev & 24.8706 & 49.8279 & 9.07 .1950 & Sokur, 1963 & $* * *$ \\
\hline Lviv, Eastern outskirts & 24.1089 & 49.8339 & 21.06 .1951 & $\begin{array}{l}\text { Tatarynov, 1956; } \\
\text { SMNH (Lviv) }\end{array}$ & $* *$ \\
\hline $\begin{array}{l}\text { Mykolaiv Region, Ochakiv District, Black Sea } \\
\text { Biosphere Reserve, Volozhin area }\end{array}$ & 31.6727 & 46.5367 & 01.01 .1967 & Gizenko, 1967 & ** \\
\hline Odessa Region, Bobrik, Kodyma River & 30.1685 & 47.91 & 10.08 .1928 & Pidoplichko, 1932 & $* * *$ \\
\hline $\begin{array}{l}\text { Odessa Region, Danube Biosphere Reserve, } \\
\text { Gneushev Island }\end{array}$ & 29.7547 & 45.442 & 23.11.1986 & Chronicle of nature DBZ & $*$ \\
\hline $\begin{array}{l}\text { Odessa Region, Danube Biosphere Reserve, } \\
\text { Kubansky Island }\end{array}$ & 29.7338 & 45.3399 & 01.07 .1985 & Chronicle of nature DBZ & $* *$ \\
\hline
\end{tabular}


Appendix 1 (continued)

\begin{tabular}{|c|c|c|c|c|c|}
\hline Place & Longitude & Latitude & Date & Reference & \\
\hline $\begin{array}{l}\text { Odessa Region, Danube Biosphere Reserve, } \\
\text { Kubansky Island }\end{array}$ & 29.757 & 45.3086 & 23.09.1992 & Chronicle of nature DBZ & $* *$ \\
\hline $\begin{array}{l}\text { Odessa Region, Danube Biosphere Reserve, } \\
\text { Ochakiv Island }\end{array}$ & 29.6707 & 45.4306 & 16.12 .1989 & Chronicle of nature DBZ & $* *$ \\
\hline $\begin{array}{l}\text { Odessa Region, Danube Biosphere Reserve, } \\
\text { Ochakiv Island }\end{array}$ & 29.6806 & 45.4299 & 18.07.1986 & Chronicle of nature DBZ & ** \\
\hline $\begin{array}{l}\text { Odessa Region, Danube Biosphere Reserve, } \\
\text { Peshchany Island }\end{array}$ & 29.6828 & 45.3837 & 15.08 .1991 & Chronicle of nature DBZ & $* *$ \\
\hline $\begin{array}{l}\text { Odessa Region, Danube Biosphere Reserve, } \\
\text { Peshchany Island }\end{array}$ & 29.6192 & 45.3829 & 01.01 .1992 & Chronicle of nature DBZ & $* *$ \\
\hline $\begin{array}{l}\text { Odessa Region, Kiliya District, vicinity of } \\
\text { Vilkovo }\end{array}$ & 29.5785 & 45.4206 & 26.08 .2009 & $\begin{array}{l}\text { Mishta A.V. (unpublished } \\
\text { data) }\end{array}$ & $*$ \\
\hline Odessa Region, Limansky District, Leski Village & 29.4883 & 45.4564 & 01.01 .2008 & $\begin{array}{l}\text { Mishta A.V. (unpublished } \\
\text { data) }\end{array}$ & $* *$ \\
\hline $\begin{array}{l}\text { Odessa Region, South-Eastern outskirts } \\
\text { of Vilkovo }\end{array}$ & 29.5682 & 45.4332 & 19.07.1996 & $\begin{array}{l}\text { Mishta, } 2008 \\
\text { IZAN } \\
\end{array}$ & $* *$ \\
\hline Poltava Region, vicinity of Poltava & 34.5786 & 49.592 & 25.05 .1944 & $\begin{array}{l}\text { Gavrilenko, } 1946 \\
\text { (1947)8; Abelentsev \& } \\
\text { Pidoplichko, } 1956 \\
\text { ZMMU }\end{array}$ & $* * *$ \\
\hline $\begin{array}{l}\text { Rivne Region, Rivne Zapovednik, Bilozerske } \\
\text { Forestry }\end{array}$ & 25.79 & 51.4784 & 29.06 .2019 & $\begin{array}{l}\text { Mishta A.V. (unpublished } \\
\text { data) }\end{array}$ & $*$ \\
\hline $\begin{array}{l}\text { Sumy Region, Glukhovsky District, floodplain } \\
\text { of Abesta River, Shalyginsky Landscape Reserve } \\
\text { of National Importance }\end{array}$ & 34.11 & 51.61 & 01.01 .1990 & $\begin{array}{l}\text { Podoprigora \& Merzlikin, } \\
2003\end{array}$ & $*$ \\
\hline $\begin{array}{l}\text { Sumy Region, Romny District, Anddriyashevsko- } \\
\text { Gudymovsky Hydrological Reserve of National } \\
\text { Importance,Ostrov Tract }\end{array}$ & 33.3384 & 50.558 & 01.01 .1984 & $\begin{array}{l}\text { Podoprigora \& Merzlikin, } \\
2003\end{array}$ & $*$ \\
\hline $\begin{array}{l}\text { Sumy Region, Seredyno-Buds'kyi District, } \\
\text { Desna-Starohutskyi National Nature Park } \\
\text { (Staraya Guta area, } 121 \text { quarter) }\end{array}$ & 33.7 & 52.32 & 02.03 .2002 & Gavris, 2007; IZAN & $* *$ \\
\hline $\begin{array}{l}\text { Sumy Region, Seredyno-Buds'kyi District, } \\
\text { Desna-Starohutskyi National Nature Park } \\
\text { (vicinity of Staraya Guta Village) }\end{array}$ & 33.6711 & 52.308 & 26.09.1999 & Gavris, 2007 & $* *$ \\
\hline $\begin{array}{l}\text { Sumy Region, Seredyno-Budskyi District, } \\
\text { Desnyansko-Starogutsky National Nature Park, } \\
\text { vicinity of Ochkino Village }\end{array}$ & 33.3288 & 52.2619 & 07.08 .2007 & Mishta et al., 2018 & $*$ \\
\hline $\begin{array}{l}\text { Sumy Region, Sumy and Lebedynskyi Districts, } \\
\text { vicinity of Petrenkovo Village }\end{array}$ & 34.6913 & 50.7711 & 25.07.1997 & Merzlikin, 1999 & ** \\
\hline Sumy Region, Sumy, vicinity of Tokary Village & 34.874 & 50.9246 & 19.12.2009 & $\begin{array}{l}\text { Merzlikin \& } \\
\text { Sheverdukova, } 2010 \\
\end{array}$ & $*$ \\
\hline $\begin{array}{l}\text { Sumy Region, Vorozhbansky Hydrological } \\
\text { Reserve }\end{array}$ & 34.6947 & 50.7668 & 03.07 .2004 & Mishta, 2008 & $*$ \\
\hline Ternopil Region, Berezhany & 24.9417 & 49.4489 & 10.05 .1950 & Sokur, 1963 & $*$ \\
\hline Ternopil Region, Chortkiv District, Uryn & 25.8287 & 48.971 & 15.05 .1950 & Sokur, 1963 & $* * *$ \\
\hline Ternopil Region, Zoborov & 25.1659 & 49.668 & 9.07 .1950 & Sokur, 1963 & $* * *$ \\
\hline $\begin{array}{l}\text { Vinnitsa Region, Bar District, Garmaki, Rovets } \\
\text { River }\end{array}$ & 27.5487 & 49.1032 & 29.09 .1927 & Pidoplichko, 1932 & $* * *$ \\
\hline Vinnitsa Region, Bershad District, Florino & 29.4986 & 48.3431 & 17.05 .1952 & Sokur, 1963 & $* *$ \\
\hline Vinnitsa Region, Borovka Village, Bushka River & 28.259 & 48.4991 & 8.09 .1927 & Pidoplichko, 1932 & $* * *$ \\
\hline Vinnitsa Region, Komargorod Village & 28.6119 & 48.5305 & 20.08 .1929 & Pidoplichko, 1937 & $*$ \\
\hline $\begin{array}{l}\text { Vinnitsa Region, Kopaigorodsky District, } \\
\text { Khrenovka (now Chernovitsky District, Privetnoe) }\end{array}$ & 27.8182 & 48.7935 & 27.10 .1928 & Pidoplichko, 1937 & $*$ \\
\hline $\begin{array}{l}\text { Vinnitsa Region, Luninets District, } \\
\text { Popelukhi Village }\end{array}$ & 28.9907 & 48.2254 & 28.11 .1928 & Pidoplichko, 1932 & $* * *$ \\
\hline Vinnitsa Region, Martinovka & 28.0204 & 49.0892 & 02.05 .1928 & Pidoplichko, 1937 & $* * *$ \\
\hline
\end{tabular}


Appendix 1 (continued)

\begin{tabular}{|c|c|c|c|c|c|}
\hline Place & Longitude & Latitude & Date & Reference & \\
\hline Vinnitsa Region, Murafa & 28.2067 & 48.7826 & 15.03 .1927 & Pidoplichko, 1929 & $* * *$ \\
\hline Vinnitsa Region, Nemercha & 27.7227 & 48.6701 & 18.07.1927 & Pidoplichko, 1932 & $* * *$ \\
\hline $\begin{array}{l}\text { Vinnitsa Region, Obodovsky District, } \\
\text { Balanovka Village }\end{array}$ & 29.3734 & 48.3932 & 15.05.1952 & Sokur, 1963 & $*$ \\
\hline Vinnitsa Region, Oratov settlement & 29.5239 & 49.1856 & 1927 & Pidoplichko, 1927 & $* * *$ \\
\hline Vinnitsa Region, Stefanovka & 28.7736 & 49.1291 & 21.08 .1929 & Pidoplichko, 1937 & $* * *$ \\
\hline $\begin{array}{l}\text { Vinnitsa Region, Vinnitsky District, Vedmezhe } \\
\text { Ushko Village }\end{array}$ & 28.313 & 49.1896 & 06.05 .1989 & Mishta, 2008 & $*$ \\
\hline $\begin{array}{l}\text { Vinnitsa Region, Vinnitsky District, vicinity } \\
\text { of Peshchanka }\end{array}$ & 28.8896 & 48.2081 & 13.03.1988 & Mishta, 2008 & $* * *$ \\
\hline Vinnitsa Region, Yakushintsy & 28.3763 & 49.2525 & 12.08 .1930 & Pidoplichko, 1937 & $* * *$ \\
\hline Vinnitsa Region, Yampil District, Dzygivka & 28.3249 & 48.3706 & $\begin{array}{l}22.09 .1927 \\
02.09 .1928\end{array}$ & $\begin{array}{l}\text { Pidoplichko, 1932; } \\
\text { Pidoplichko, } 1937\end{array}$ & $* * *$ \\
\hline Vinnitsa Region, Zhmerynka District, Severinovka & 27.9468 & 49.0557 & 18.04.1928 & Sokur, 1963 & $* *$ \\
\hline $\begin{array}{l}\text { Vinnitsa Region, Zhmerynka District, } \\
\text { Severinovka, Rov River }\end{array}$ & 27.9473 & 49.0561 & 18.07.1927 & Pidoplichko, 1929 & $* * *$ \\
\hline $\begin{array}{l}\text { Vitebsk Region, Ushachsky District, Vashkovo } \\
\text { Village, Borkovschina Lake }\end{array}$ & 28.6004 & 55.1058 & 11.07 .1905 & Savarin, 2019 a, b, c & $* *$ \\
\hline $\begin{array}{l}\text { Vitebsk Region, Ushachsky District, Vashkovo } \\
\text { Village, Dolzhina Lake }\end{array}$ & 28.6009 & 55.1094 & 11.07.1905 & Savarin, 2019 a, b, c & $* *$ \\
\hline $\begin{array}{l}\text { Vitebsk Region, Ushachsky District, Vashkovo } \\
\text { Village, Vechelye Lake }\end{array}$ & 28.6103 & 55.1321 & 11.07.1905 & Savarin, 2019 a, b, c & $* *$ \\
\hline Volyn Region, Kamin-Kashyrskyi & 24.9933 & 51.6368 & 27.06 .1949 & Sokur, 1963 & $* * *$ \\
\hline Volyn Region, Klevan & 25.97 & 50.75 & 14.06.1949 & Sokur, 1963 & $* * *$ \\
\hline Volyn Region, Luboml & 24.0483 & 51.2275 & 21.06 .1949 & Sokur, 1963 & $*$ \\
\hline Volyn Region, Manevychi District, Povorsk & 25.1588 & 51.2703 & 28.06 .1949 & Sokur, 1963 & $* * *$ \\
\hline Volyn Region, Shatsk & 23.9602 & 51.4888 & 24.06 .1949 & Sokur, 1963 & $* *$ \\
\hline $\begin{array}{l}\text { Volyn Region, Shatsky District, Zatishye Village, } \\
\text { Northern shore of Luky Lake }\end{array}$ & 23.8366 & 51.5824 & 22.06 .2004 & Zatushevskiy et al., 2010 & $*$ \\
\hline Zakarpattia Region, Beregi & 22.7826 & 48.2529 & 29.08 .1946 & Sokur, 1963 & $* * *$ \\
\hline Zakarpattia Region, Beskidy, Volonets Village & 23.1975 & 48.6979 & 05.08 .1950 & $\begin{array}{l}\text { Tatarynov, 1956; SMNH } \\
\text { (Lviv) }\end{array}$ & * \\
\hline $\begin{array}{l}\text { Zakarpattia Region, Byerazino District, Uzhok } \\
\text { Village }\end{array}$ & 22.9299 & 48.9893 & 01.07 .1961 & ZM UzhNU & $* *$ \\
\hline $\begin{array}{l}\text { Zakarpattia Region, Carpathian Biosphere } \\
\text { Reserve, central office }\end{array}$ & 24.2229 & 48.0437 & 01.01 .1987 & Zagorodnyuk et al., 1997 & $* *$ \\
\hline $\begin{array}{l}\text { Zakarpattia Region, Carpathian Biosphere } \\
\text { Reserve, Chernogorka }\end{array}$ & 24.4798 & 48.1121 & 01.01 .1987 & $\begin{array}{l}\text { Zagorodnyuk et al., } 1997, \\
1997\end{array}$ & $* *$ \\
\hline $\begin{array}{l}\text { Zakarpattia Region, Carpathian Biosphere } \\
\text { Reserve, Kuziysky area }\end{array}$ & 24.1598 & 48.0001 & 1987-1994 & $\begin{array}{l}\text { Zagorodnyuk et al., } 1997, \\
1997\end{array}$ & $* * *$ \\
\hline $\begin{array}{l}\text { Zakarpattia Region, Carpathian Biosphere } \\
\text { Reserve, Marmorossky area }\end{array}$ & 24.45 & 48.1 & 1987-1994 & $\begin{array}{l}\text { Zagorodnyuk et al., } 1997, \\
1997\end{array}$ & $* * *$ \\
\hline $\begin{array}{l}\text { Zakarpattia Region, Carpathian Biosphere } \\
\text { Reserve, Shirokoluzhansky area }\end{array}$ & 23.772 & 48.2328 & 1987-1994 & $\begin{array}{l}\text { Zagorodnyuk et al., 1997, } \\
1997\end{array}$ & $* * *$ \\
\hline $\begin{array}{l}\text { Zakarpattia Region, Carpathian Biosphere } \\
\text { Reserve, Ugolsky area }\end{array}$ & 23.6102 & 48.2127 & 01.01 .1987 & Sokur, 1963 & $*$ \\
\hline Zakarpattia Region, Chornogora & 24.6108 & 48.0541 & 19.08.1961 & NMNH & $*$ \\
\hline $\begin{array}{l}\text { Zakarpattia Region, Irshavsky District, vicinity } \\
\text { of Dolgoe Village }\end{array}$ & 23.2946 & 48.3834 & 08.09 .1990 & Zatushevskiy et al., 2010 & $*$ \\
\hline Zakarpattia Region, Irshavsky District, Zagate & 22.9567 & 48.3988 & 28.05 .1948 & Sokur, 1963 & $*$ \\
\hline Zakarpattia Region, Kosteva Pastil & 22.541 & 48.8522 & 31.08 .1948 & Sokur, 1963 & $*$ \\
\hline Zakarpattia Region, Maly Bereznyi & 22.4511 & 48.8628 & 01.09 .1948 & Sokur, 1963 & $* *$ \\
\hline Zakarpattia Region, Menchil & 23.6605 & 48.31 & 02.06 .1963 & NMNH (Kyiv) & $* *$ \\
\hline
\end{tabular}


Appendix 1 (continued)

\begin{tabular}{|c|c|c|c|c|c|}
\hline Place & Longitude & Latitude & Date & Reference & \\
\hline Zakarpattia Region, Mukachevo & 22.6797 & 48.4393 & 11.12 .1947 & Sokur, 1963 & $* *$ \\
\hline $\begin{array}{l}\text { Zakarpattia Region, Mukachevo District, } \\
\text { Sinyak Village }\end{array}$ & 22.8523 & 48.5799 & 10.06.1965 & ZM NUK & $* *$ \\
\hline $\begin{array}{l}\text { Zakarpattia Region, Perechyn District, Turi } \\
\text { Remety }\end{array}$ & 22.5988 & 48.7012 & 02.05 .1948 & Sokur, 1963 & $* * *$ \\
\hline $\begin{array}{l}\text { Zakarpattia Region, Rakhovsky District, Kvasovy } \\
\text { Menchul }\end{array}$ & 24.3278 & 48.1732 & 01.09 .1972 & ZM UzhNU & $*$ \\
\hline $\begin{array}{l}\text { Zakarpattia Region, Rakhovsky District, vicinity } \\
\text { of Yasynya Village, Lopushanka River, Portoshi } \\
\text { Tract }\end{array}$ & 24.3898 & 48.2298 & 01.08 .1986 & ZM UzhNU & $*$ \\
\hline Zakarpattia Region, Sheshul, Baskul Tract & 24.3732 & 48.1529 & 01.01 .1950 & $\begin{array}{l}\text { NMNH (Kyiv), SMNH } \\
\text { (Lviv) }\end{array}$ & $* *$ \\
\hline $\begin{array}{l}\text { Zakarpattia Region, Svaliava District, Vilchy } \\
\text { Village }\end{array}$ & 23.1039 & 48.5952 & 07.1965 & ZM UzhNU & $* * *$ \\
\hline Zakarpattia Region, Tiachiv District & 23.7101 & 48.3079 & 25.06 .1954 & ZIN RAS & $* *$ \\
\hline Zakarpattia Region, Tiachiv District, Bradul Tract & 23.9663 & 48.4633 & 01.09 .1963 & ZM NUK & $* *$ \\
\hline $\begin{array}{l}\text { Zakarpattia Region, Tiachiv District, Goverlyanka } \\
\text { River }\end{array}$ & 24.4699 & 48.1404 & 01.05 .1963 & ZM NUK & $* *$ \\
\hline Zakarpattia Region, Tiachiv District, Grushevo & 23.7689 & 48.0104 & 28.05 .1948 & Sokur, 1963 & $* *$ \\
\hline Zakarpattia Region, Tiachiv District, Uglya & 23.6288 & 48.1487 & 14.05.1948 & Sokur, 1963 & $* *$ \\
\hline $\begin{array}{l}\text { Zakarpattia Region, Tiachiv District, vicinity } \\
\text { of Bolshaya Ugolka Village }\end{array}$ & 23.67 & 48.2 & 01.08 .1978 & ZM UzhNU & $* *$ \\
\hline Zakarpattia Region, Tyachev & 23.5969 & 48.0083 & 28.05.1948 & Sokur, 1963 & $* * *$ \\
\hline $\begin{array}{l}\text { Zakarpattia Region, Uzhhorod District, Maly } \\
\text { Bereznyi }\end{array}$ & 22.4514 & 48.8672 & 09.11 .1955 & ZIN RAS & $* *$ \\
\hline Zakarpattia Region, Velykyi Bereznyi & 22.4611 & 48.8863 & 29.08 .1948 & Sokur, 1963 & $* *$ \\
\hline $\begin{array}{l}\text { Zakarpattia Region, Vynohradiv District, } \\
\text { Bolshie Komyaty }\end{array}$ & 22.9809 & 48.2464 & 03.06 .1948 & Sokur, 1963 & $* *$ \\
\hline Zhytomyr Region, Borushkovtsy & 27.656 & 49.9746 & 02.05 .1928 & Pidoplichko, 1932 & *** \\
\hline Zhytomyr Region, Liubar District, Glezno & 27.7067 & 49.9794 & 24.07.1929 & Pidoplichko, 1937 & *** \\
\hline Zhytomyr Region, Liubar District, Korostki & 27.7434 & 49.9954 & 06.09 .1926 & Pidoplichko, 1932 & $* * *$ \\
\hline Zhytomyr Region, Malinsky District, Fedorovka & 29.3694 & 50.7053 & $\begin{array}{c}07.09 .1926 \\
07.1927 \\
01.06 .1930 \\
\end{array}$ & Pidoplichko, 1932, 1937 & * \\
\hline Zhytomyr Region, Mala Tsvilka & 27.549 & 50.7427 & 31.07 .1929 & Pidoplichko, 1932 & *** \\
\hline $\begin{array}{l}\text { Belarus, Brest Region, Baranovichi District, } \\
\text { wet alder forest on River Bank }\end{array}$ & 25.6649 & 52.9898 & 20.08.1997 & Mishta, 2011 & $*$ \\
\hline $\begin{array}{l}\text { Belarus, Brest Region, Kamenets District, } \\
\text { Bialowieza Forest }\end{array}$ & 24.9958 & 52.5181 & 15.08 .2015 & $\begin{array}{l}\text { Savarin \& Molosh, 2017; } \\
\text { Savarin, } 2019 \text { a, b,c }\end{array}$ & $*$ \\
\hline $\begin{array}{l}\text { Belarus, Vitebsk Region, Lepelsky District, } \\
\text { Berezinsky Biosphere Reserve (Test site } \\
\text { "Sinicheno", forest quarter } 444 \text { and test site } \\
\text { "Savsky Bor", forest quarter 401) }\end{array}$ & 28.1908 & 54.7147 & 15.07.1998 & $\begin{array}{l}\text { Kashtalyan, 1999; } \\
\text { Kashtalyan \& Springer, } \\
2012\end{array}$ & $*$ \\
\hline $\begin{array}{l}\text { Belarus, Vitebsk Region, Ushachsky District, } \\
\text { Vashkovo Village, Borkovschina Lake }\end{array}$ & 28.6013 & 55.1051 & 11.07.1905 & Savarin, 2019 a, b,c & $*$ \\
\hline Lithuania, Delta of Neman River & 21.2851 & 55.2477 & 01.01 .2009 & $\begin{array}{l}\text { Balčiauskas \& } \\
\text { Balčiauskiene, 2012; } \\
\text { Balčiauskas et al., 2016 }\end{array}$ & $*$ \\
\hline
\end{tabular}

